\title{
Arte contemporânea em diálogo com a tradição visual: Cardoso, Zocchio e Navas (São Paulo, 1887-2016)
}

\author{
Contemporary Art in dialogue with the Visual Tradition: Cardoso, Zocchio and \\ Navas (São Paulo, 1887-2016)
}

http://dx.doi.org/10.1590/1982-02672019v28e03

\section{RICARDO MENDES}

https: / / orcid.org/0000-0003-0959-2498

Arquivo Histórico Municipal de São Paulo - SMC-PMSP / São Paulo, SP, Brasil

RESUMO: Estruturado em três segmentos, o artigo comenta em um primeiro momento ensaios visuais dos artistas contemporâneos Patrícia Cardoso, Marcelo Zocchio e Thiago Navas que tomam a cidade de São Paulo e suas representações como questão, em ações que tensionam aspectos como memória, autoria, autoridade e tradição visual.

Em seguida, é apresentado um percurso historiográfico sobre a obra de Militão Augusto de Azevedo (Rio de Janeiro, 1837-São Paulo, 1905), produtor visual em destaque na reflexão operada naqueles ensaios. Surge ali como referência em diferentes graus e modos o Álbum comparativo da cidade de S. Paulo (1862-1887), o mais extenso conjunto imagético sobre a cidade ao final da década de 1880. Busca-se destacar como as imagens de Militão foram percebidas e mobilizadas no processo de construção de uma memória urbana local ao longo do século XX e, por fim, na própria constituição do campo da história da fotografia brasileira. $\bigcirc$ artigo retorna ao final à análise dos ensaios de Cardoso, Zocchio e Navas, comentando como operam sobre princípios estruturais como o recurso comparativo entre fotografias, as funções documentais, representacionais, etc. $\bigcirc$ artigo enfoca especialmente as temporalidades articuladas pela narrativas imagéticas no álbum de Militão e nas apropriações posteriores, e como uma potente reflexão sobre esses aspectos se realiza no segmento da arte contemporânea, permitindo expor as dinâmicas que submeteram a iconografia histórica local a agendas diversas.

\begin{abstract}
1. Graduação em Arquitetura pela Faculdade de Arquitetura e Urbanismo da Universidade de São Paulo (USP), graduação em Cinema pela Escola de Comunicações e Artes da mesma Universidade. Mestrado em Biblioteconomia / linha Ação Cultural pela ECA/USP; doutorando em História Social pela FFLCH-USP. Desenvolve desde 1997 o projeto de referência FotoPlus sobre história da fotografia no Brasil (<http:/ www.fotoplus.com>). É pesquisador aposentado pelo Arquivo Histórico Municipal de São Paulo-SMC. E-mail: <rico1955@usp.br>
\end{abstract}


PALAVRAS-CHAVE: Arte contemporânea. Tradição visual. Temporalidade. Fotografia. Militão Augusto de Azevedo. São Paulo (cidade).

ABSTRACT: The article, structured in 3 segments, comments some visual essays by contemporary artists Patrícia Cardoso, Marcelo Zocchio and Thiago Navas, which take the city of São Paulo and its representations as subject, working with aspects as memory, authorship, authority and visual tradition.

Following the article presents a historiographical panorama about the work of Militão Augusto de Azevedo (Rio de Janeiro, 1837-São Paulo, 1905), a prominent visual producer, whose images are central for those essays. Militão Azevedo's Álbum comparativo da cidade de S. Paulo (1862-1887), the most extensive imagery set about the city at the end of the 1880s, is a reference in different degrees and modes in such contemporary artworks. This paper seeks also to highlight how the images of Militão were perceived and mobilized throughout the 20th century in the process of building a local urban memory and in the very constitution of the field of the history of Brazilian photography.

The article concludes with the analysis of Cardoso, Zocchio and Navas' works, commenting the ways they operate on structural principles such as the comparative resource between photographs, documentary and representational functions etc. The text focuses on the temporalities articulated by the imagetic narratives in Militão's album and the later appropriations, and seeks to feature the potent reflection that takes form in the segment of contemporary art, which reveals the dynamics that had subjected the local historical iconography to different agendas.

KEYWORDS: Contemporary Art. Visual tradition. Temporality. Photography. Militão Augusto de Azevedo. São Paulo (city). 
2. Fala de Fernando Pião, na nota: Exposição: "Outra Margem" se despede da Oficina Oswald de Andrade. SP Notícias, site, 13 de julho de 2003, Eventos. Disponível em: <http://bit.ly/2PbjbrE>. Acesso em: 26 jun. 2018.

2003, Oficina Cultural Oswald de Andrade. Jovens artistas, de origens diversas, encontram-se para discutir "a produção contemporânea a partir do suporte fotográfico". Nas palavras de um dos participantes, "a construção/ficção da imagem, a negação do referente e a descrença na linguagem é o fio que liga nossas inquietações..." 2 Reunidos meses depois na mostra Outra margem, dentre os seis artistas participantes, Patrícia Cardoso (São Paulo, 1972) apresenta dois dípticos fotográficos de pequeno formato. ${ }^{3}$

As imagens, registros urbanos, comungam quase de uma banalização de cenas do cotidiano da rua. Suas legendas, contudo, ativam com contundência a ação conceitual. Exigem para isso um espectador familiarizado em certa medida com a iconografia paulista. Num dos dípticos, a artista contrapõe uma cena da Rua Washington Luís, no centro da cidade, região comercial ativa, embora degradada, à Avenida Washington Luís, na região do Aeroporto, a mais de 10 km de distância, em outro contexto social.

A esse espectador "ativo", a estratégia do projeto é clara e até mesmo potente. Remete à prática visual que marca a constituição das relações entre fotografia e cidade em São Paulo. Uma ação comparativa se estabelece. $\bigcirc$ que une as imagens, salvo a simultaneidade temporal vaga entre espaços distantes, é o nome dos logradouros, referência a pessoas e eventos da história local. $\bigcirc$ que adere esses nomes a espaços distintos, qual a relação entre eles, entre objetos e formas presentes nas imagens? Expressa algo a denominação? Algo de materialmente comum? Ou no sentido contrário, é a falta de elos que se revela? Como veremos, a estratégia narrativa da imagem comparativa, aspecto recorrente no contexto da iconografia local, será subvertida.

Através desse gatilho, conciso e enigmático, as obras de Cardoso permitiram antever possibilidades de aproximação a um conjunto iconográfico de centralidade no quadro local por parte de outras gerações de produtores visuais. $\bigcirc$ presente ensaio segue essa linha de desenvolvimento, a partir da análise da produção de Cardoso e de outros dois artistas - Marcelo Zocchio e Thiago Navas -, todos os três atuantes nas décadas de 2000 e 2010, cujas obras em questão mantêm relação direta e crítica com a história (e historiografia) da fotografia local.

Constituídas em contraponto ${ }^{4}$ à publicação Álbum comparativo da cidade de S. Paulo (1862-1887), de Militão Augusto de Azevedo (Rio de
3. O evento teve lugar entre 15 de maio e 28 de junho de 2003 na Oficina Cultural Oswald de Andrade, em São Paulo. As obras de Cardoso, nas dimensões $50 \times 70 \mathrm{~cm}$ (cada foto), são intituladas Rua Washington Luís, Centro, SP/Av. Washington Luís, Aeroporto, SP (2003) e Rua 9 de Julbo, Santo Amaro, SP / Av. 9 de Julbo, Jardins, $S P$ (2003). A artista atua então, entre outros segmentos, na fotografia de arquitetura, não tendo retomado em sua produção a temática presente nas obras expostas. de ser considerado excessivo, restringindo a relevância das obras em análise a uma única interpretação. No entanto, essa avaliação é pertinente como veremos ao longo do ensaio sem ferir a potência das imagens.
4. O termo contraponto po- 
5. Seria oportuno apontar que as pesquisas ao redor da obra de Militão Azevedo, nas décadas de 1970 e 1980, constituem núcleo importante da produção do período em que se delineia efetivamente uma primeira fase da historiografia da fotografia no Brasil, aqui caracterizada pela produção predominante de autores fora do universo acadêmico em contexto que antecede à (re)estruturação institucional de acervos fotográficos brasileiros. Esse aspecto formativo do campo colabora, ainda que em segundo plano, na construção de uma centralidade para parte da obra de Militão.

Para uma referência de apoio sobre a história da fotografia local, além das mencionadas em notas e na bibliografia final do ensaio, recomenda-se ainda a base bibliográfica no site FotoPlus (disponível em: www.fotoplus.com). Cf. Goulart; Mendes (2007).

6. Toma-se para isso a bibliografia e os debates realizados no âmbito da disciplina FLS5291-2 -Antropologia do tempo e da temporalidade (PPG em Antropologia Social), ministrada pelo professor João Felipe Gonçalves no primeiro semestre de 2018 (FFLCH-USP).
Janeiro, 1837-São Paulo, 1905), mais extenso conjunto imagético sobre a cidade de então, lançado comercialmente pelo fotógrafo ao final da década de 1880, as ações realizadas por estes artistas visuais questionam princípios estruturais dessa referência como o recurso comparativo entre fotografias, a função documental do registro e as intervenções sobre a temporalidade das imagens em jogo. Este último elemento é traço - contaminante e de retorno contínuo - presente no álbum e em reelaborações realizadas em momentoschave ao longo do século XX.

A proposta do ensaio é aproximar criticamente essas produções com ênfase sobre a questão da temporalidade, bem como analisar o locus estabelecido pelo pensamento crítico em fotografia sobre a obra em questão de Militão de Azevedo em estudos historiográficos e ações de institucionalização da memória local que se deram a partir de meados da década de 1970.5 Essa abordagem é proposta agora sob a luz de conceitos e questões próprias de uma antropologia do tempo, campo crítico mais recente. ${ }^{6}$

Ressalve-se que a obra de Militão de Azevedo será apresentada de modo sumário, apenas para garantir inteligibilidade a um público maior. Será enfatizado, quando necessário, o percurso de sua difusão e recorrência ao longo do tempo, pontuando-se enfaticamente ações mobilizadoras que, caso expressivo no quadro brasileiro, revelam modos de agenciamento sobre temporalidade.



RUA 9 DE JULHO
SANTO AMARO, SP

Figura 1 - Patrícia Cardoso. Rua 9 de Julho - Santo Amaro, SP / Avenida 9 de Julho - Jardins, $S P(2003)$, díptico, fotografia colorida, a partir de cromo, dimensões $50 \times 140 \mathrm{~cm}$. Acervo pessoal da artista. 


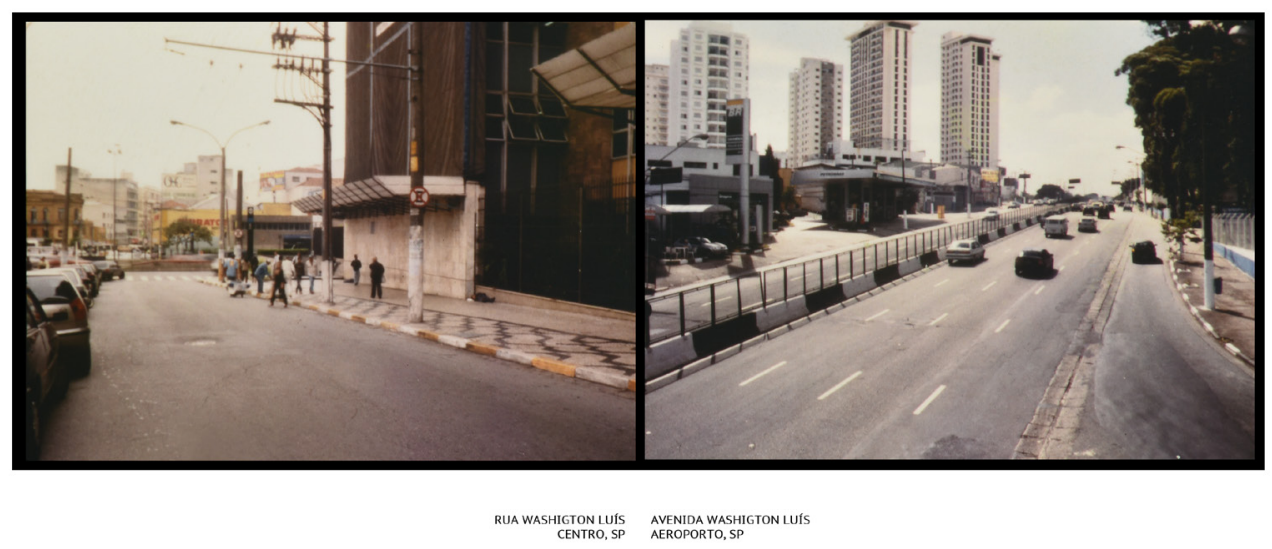

Figura 2 - Patrícia Cardoso. Rua Washington Luís - Centro, SP / Avenida Washington Luís Aeroporto, SP (2003), díptico, fotografia colorida, a partir de cromo, dimensões $50 \times 140 \mathrm{~cm}$. Acervo pessoal da artista.

Antes de avançar nessa direção, seria oportuno comentar as obras de Zocchio e Navas, que junto com os dípticos de Cardoso constituem o centro de interesse do ensaio. Como Cardoso, ambos participam de uma condição nova do contexto cultural, que merece atenção, pois estimulou o pensamento em perspectivas transversais por segmentos como artes visuais e fotografia e uma percepção atenta a questões estruturais da produção, circulação e institucionalização de bens simbólicos.

As quase duas gerações de artistas visuais, cujas formação e produção se deram a partir da virada para o século XXI, atuaram em contexto distinto das anteriores. Por um lado integram - como público e como participantes diretos - um circuito de produção e difusão de obras de arte sob uma dinâmica até então inexistente no panorama brasileiro, caracterizada pela presença de instituições e ações com bases mais regulares, com circulação internacional (e intranacional) de obras visuais e de textos intensificada, bem como por uma diversificada matriz de formação (pública e privada), formal ou não, de cursos de curto prazo a programas de graduação e pós-graduação.?

Essa condição nova - de circulação de obras, troca de informação, educação, etc. - está sujeita certamente às dinâmicas socioeconômicas brasileiras e às suas desigualdades estruturais de curto e longo prazos. Está sujeita ainda à convivência com práticas mais próximas ao momento anterior, como por exemplo modalidades preexistentes do mercado de arte. No entanto, outro aspecto deve ser apontado. Entremeado a esta condição, o estatuto das artes e da cultura na contemporaneidade é outro, mais heterogêneo e híbrido,
7. Não cabe aqui caracterizar estruturalmente essa condição nova do campo das artes visuais, mas consideramos necessário apontar que os índices mais evidentes - aumento de fluxo e dinâmica de geração e circulação de obras e informação - atingem boa parte dos seus agentes - produtores de obras, agentes institucionais em largo espectro, etc. - e os públicos da arte, também estes em recorte ampliado. 
8. Apenas um exemplo, a mostra Identidade não identidade: a fotografia brasileira nos anos 80-90, sob curadoria de Tadeu Chiarelli, realizada no MAM São Paulo e Centro Cultural Light (Rio de Janeiro), em 1997. Não apenas boa parte dos artistas participantes terão destaque nos anos seguintes, mas até mesmo seu curador será peça importante nessa confluência entre fotografia e artes visuais como acadêmico (ECA-USP), como curador e como gestor de instituições-chave: MAC-USP, MAM São Paulo e Pinacoteca de São Paulo. Com destaque, nestas duas últimas, sua presença foi fundamental para agilizar a incorporação de obras fotográficas dessa geração de produtores visuais aos acervos.

9. Apenas um exemplo, nesse quadro aqui delineado: tome-se a atuação do grupo Panoramas da imagem, em São Paulo, formado por Everton Ballardin, José Fujocka Neto e Rubens Mano, e mais tarde Eli Sudbrack. Entre 1993 e 1998 , promovem exposições a partir de convocatórias nacionais, além de debates e oficinas com participação de artistas locais e estrangeiros. Ativo anos antes do que seria denominado como coletivo de artistas, nas ações do grupo quanto a gestão de projetos, educação e formação de público, já estão presentes modos de operação em rede e nelas se intensificam os laços entre artistas visuais mais novos, de São Paulo e de outros estados, com apoios eventuais de instituições de fomento, de museus e do mercado de arte.

10. Foge ao escopo do ensaio refletir longamente sobre essa produção. Tal conjunto foi tema de três encontros no curso São Paulo: fotografia contemporânea da cidade, ministrado pelo autor no Centro de Pesquisa e Formação (Sesc-SP), em abril de 2016 (disponível em formas e procedimentos, acompanhando aqui parte de tendências internacionais da produção de bens.

Marcelo Zocchio (São Paulo, 1963), fotógrafo, com atuação em publicidade e outros setores, mantém produção regular em artes visuais a partir da década de 1990. O período marca a entrada de uma nova geração de artistas, com formação em artes visuais e fotografia, ainda heterogênea, mas que parece distante das anteriores, superando lou, digamos, aproximando-se de modo distinto a) questões como a presença da fotografia nas artes visuais para problematizá-la como um dos traços da visualidade contemporânea.

Zocchio toma parte nesse movimento seja em exposições no circuito institucional que acabam elas mesmas por promover a atualização de acervos, ${ }^{8}$ seja em espaços alternativos que começam a surgir, promovendo uma circulação paralela ao sistema institucional e ao mercado de arte, com os quais aqueles artistas manterão interações de diferentes gradações e modos. ${ }^{9}$

Zocchio, como parte dessa geração, discute em sua produção a paisagem urbana. Esses artistas apresentam ações sobre esta temática de forma contínua, complexa e com grande centralidade. Afastam-se, porém, da categoria "fotografia de rua", que se constituiu como gênero anteriormente cristalizado a partir de um formato marcado desde os anos de 1940 e 1950 pela influência de uma fotografia humanista de forte difusão entre nós, em geral de origem francesa e depois, na década de 1970, com maior influência norte-americana. Agora, esses novos artistas, recorrendo à fotografia, à performance, ao vídeo etc., refletem sobre a cidade, indo além do imaginário de uma primeira modernidade como constituída no século anterior, mas da cidade como palco de relações humanas, território de estruturas econômicas e culturais invisibilizadas, que serão articuladas conceitualmente, e da cidade como espaço da ação direta dos artistas, o que se dá muitas vezes de modo colaborativo. ${ }^{10}$

A série Repaisagem, de longa duração, iniciada em 2005, constitui a obra em análise. " Resumir um conjunto tão extenso e complexo demandaria um mapeamento mais atento, porém um esboço pode antecipar o que interessa agora. À primeira vista, a cidade surge como registro urbano, facilmente reconhecível. As imagens oferecem-se num viés banal, mas, repentinamente, essa Gestalt primeira introduz um índice de perturbação, que põe em crise a percepção inicial. $\bigcirc$ que parece familiar, marcas do espaço e seu uso, pois fruto de repetido registro e reprodução reiterativa na iconografia paulistana, surge como elemento estranho, oximoro temporal. Ao espectador, não necessariamente um conhecedor da cidade, daquela região em foco, mas ainda assim agente ativo, o gatilho da ação artística é revelado. ${ }^{12}$ 
estranhamento que aí tem lugar surge ao identificarmos que a imagem da rua, da praça, é em verdade composta por fragmentos de outros registros fotográficos, com índices materiais de diferentes períodos. A perícia da execução e a coincidência espacial de temporalidades distintas, baseada na marca indicial da fotografia, são aqui utilizadas para confrontar temporalidades sob uma mesma (como se fosse possível) espacialidade. ${ }^{13}$ A prática da imagem comparativa acontece aqui estruturada num único registro, ironizando o estatuto da fotografia documental. Por ora, esse resumo é suficiente.

Thiago Navas (São Paulo, 1981 ), artista visual, graduado em artes, traço representativo de produtores de presença mais recente, surge com uma série disruptiva em mostra individual realizada em 2016 na Caixa Cultural São Paulo. $\bigcirc$ título da mostra trai parte do procedimento adotado nas obras: Apagamentos. termo é comum na produção artística contemporânea e na reflexão teórica, integrando uma nuvem de conceitos próximos, mas não símiles, como ocultamento, invisibilidade, silêncio, esquecimento. Aqui, porém, o conceito é transformado em ação contínua vigorosa.

Navas retoma imagens persistentes entre nós, resultado de uma recorrência centenária: as fotografias de Militão. Na série Apagamentos/ Encobrimentos (2015-W2016), cenas urbanas, em imagens impressas, elas mesmas páginas representativas da historiografia, ${ }^{14}$ estão sujeitas a dois procedimentos, próximos numa primeira percepção, embora distintos enquanto prática e desdobramento conceitual.

Em parte do conjunto, ruas centenárias, em suas formas tão conhecidas, têm a massa das edificações oculta por camadas de tinta preta. Às vezes alguns habitantes, passantes, têm suas imagens preservadas e, mais raramente, uma edificação permanece ainda visível. $\bigcirc$ estranhamento está aqui mais próximo do sinistro, da atmosfera do filme noir. ${ }^{15}$

Em outra parte da série, as páginas são objeto de eliminação física de parte das imagens. As edificações, seus registros, são lixadas, apagadas habilmente. Agora mero vulto, fantasmático, entre enigma ou ameaça, o fato arquitetônico se revela apenas pela linha do telhado ou chanfro junto ao solo. A cidade reduz-se à "rua", ao espaço entre planos verticais. Surge, repentinamente, algo até então invisível, o chão que se pisa e uma estranha luz que tudo banha. ${ }^{16}$ Aqui não opera mais o procedimento comparativo da obra original, mas uma ação que parece provocar o próprio registro, a fotografia original, e devolve nós e Militão - ao presente imediato. registro em áudio na unidade).

11. Publicada em parte, em Zocchio (2012), em versões impressa e ePUB, a série tem produção contínua entre 2005 e 2015, aproximadamente. Ela se realiza em paralelo a outra série, também de longa duração, intitulada Utilidades domésticas, que entre outros aspectos explora as representações em confronto com os objetos referentes, no caso móveis e artefatos em madeira. Sobre esta última série, cf. o catálogo Marcelo Zocchio e a imagem materializada (Pinacoteca de São Paulo, 2016).

12. A estratégia proposta ao longa da série pelo artista mantém-se aparentemente em funcionamento mesmo para espectadores com diferentes experiências sobre a cidade e suas representações. Merece atenção que esse dispositivo consegue se manter ativo, muito além da sedução momentânea. A operação é sustentada (e renovada) habilmente ao longo dos mais de dez anos de elaboração do conjunto.

13. Guilherme Wisnik, pesquisador e crítico em arquitetura, na edição do livro sobre o projeto em 2012 (n.p.), designa o que ocorre como uma "temporalidade invasiva".

14. Trata-se de páginas de Fernandes Jr.; Barbuy; Frehse (2012). Com textos de especialistas em história da fotografia, antropologia e história - Rubens Fernandes Junior, Fraya Frehse e Heloisa Barbuy, esse "substrato" da obra de Navas ganha aura carregada de autenticidade e oficialidade. Por um lado, o acervo da Casa da Imagem, unidade da Secretaria Municipal de Cultura, um dos editores da publicação, constitui-se, junto com o Museu Paulista-USP e a Biblioteca Mário de Andrade, como um dos três núcleos principais 
responsáveis, até a década de 1980 , pela reunião e conservação dos registros fotográfico da cidade produzidos entre as décadas de $1860 \mathrm{e}$ 1920 , o que envolve o conjunto de imagens num contexto de memória urbana reconhecida institucionalmente. Por outro lado, a associação da publicação ao selo editorial da empresa Cosac Naify, que ao longo de 20 anos alcançou status de excelência gráfica e prestígio no segmento cultural brasileiro, acrescenta nova carga simbólica à série de Navas.

15. O recurso do apagamento, da eliminação parcial de um registro apropriado, não é único na produção contemporânea recente. Ocorre de forma próxima, por exemplo, no livro de Tassinari (2017), em que no temário da memória pessoal a autora intervém em imagens de $s l i$ des de viagem do avô, encobrindo partes das imagens, como já destaca a capa da publicação. Outro exemplo, embora utilizando reproduções de gravuras de Jean Baptiste Debret, é obra da série Papiro, de Marcelo Massagão, Homens Brancos (2018, $20 \times 700$ $\mathrm{cm}$, em caixa), na qual eliminados os "brancos" restam em evidência os escravos a seus serviços.

16. Menciono a luz que banha as ruas, porque é esta a informação nova, que a intervenção gera. $\mathrm{O}$ registro do céu na fotografia de paisagem em meados do século XIX era um aspecto técnico crucial. As imagens fotográficas por longo tempo não conseguiam captar com igual qualidade num mesmo registro aspectos do céu e da paisagem como o terreno e as edificações. Daí o recurso de montagens eventuais ou retoques como alternativa. Muitas vezes trechos das imagens do céu eram eliminados intencionalmente para corrigir o resultado do
A partir dos ensaios visuais dos artistas contemporâneos Patrícia Cardoso, Marcelo Zocchio e Thiago Navas, que tomam a cidade de São Paulo e suas representações como questão, é possível pensar as operações dos seus autores que tensionam conceitos como memória, autoria e autoridade no recorte da tradição visual paulistana, na qual a obra de Militão tem centralidade.

É oportuno rever brevemente como operamos com esses conceitos na presente abordagem. Sobre autoria, no sentido usual, como relativo ao criador (ou criadores, no quadro da modernidade), ao produtor das obras, o conceito tanto é tomado no sentido expandido usual na arte contemporânea através da apropriação, da inserção em nova circunstância, modelo que se aplica a diversos meios de expressão, da alta cultura a correntes da música popular, de massa, etc., como também é proposto aqui associado eventualmente a agentes diretos de comissionamento, privado ou público. No percurso traçado a seguir, comentase a interação do conceito autoria com o de autoridade. Aplicado tanto ao autor como em modo expandido ao circuito de difusão, no qual outros agentes editoriais ou institucionais estão presentes, procura-se evidenciar como interagem no investimento de capital simbólico, cultural, intelectual. Nesse sentido, é possível observar a excepcionalidade do fenômeno ao redor da produção de Militão no recorte da história da fotografia regional e nacional, por sua extensão, complexidade e longa duração.

A partir do conjunto de ações em análise, o ensaio propõe a discussão das obras de Cardoso Zocchio e Navas enquanto reflexões sobre aspectos da construção de uma tradição visual paulistana quanto a representações do espaço urbano, em que a fotografia, na falta de uma produção iconográfica mais extensa anterior ao século XIX, é veículo central. Em certos aspectos, a aproximação entre tradição visual e memória, em suas dimensões do pessoal ao coletivo, como convencionalização, modelagem, etc., é posta em jogo, em crise, de modo marcante nas obras de Thiago Navas. ${ }^{17}$

Nesse percurso, o ensaio opera em sua análise com as dimensões propostas por Meneses: ${ }^{18}$ (a) os sistemas de comunicação visual (produção, circulação, consumo...); (b) as esferas de poder, sistemas de controle, regimes de visibilidade, etc.; e (c) os instrumentos e técnicas de observação, e modalidades do "olhar". Voltaremos aos ensaios contemporâneos após rever parte do percurso das imagens oitocentistas da cidade sob essa perspectiva. 
Há uma coincidência entre os estudos iniciais sobre a obra de Militão, tanto sobre o autor ${ }^{19}$ quanto ao registro documental e as representações da cidade de São Paulo, e a constituição no Brasil de um campo da história da fotografia (ou, ao menos, de campos associados nessa direção). ${ }^{20}$ A década de 1970 marca a gênese da historiografia dedicada ao setor, algo paradoxal considerando-se a intensa prática e diversidade dessa produção desde 1840, aspecto porém presente em outras historiografias fora dos EUA e da Europa Ocidental. Os motivos dessa ocorrência fogem ao escopo do artigo, mas seria oportuno lembrar que é a partir do interesse por antigos registros fotográficos urbanos que começam a serem elaboradas pesquisas históricas relevantes a uma futura história da fotografia no Brasil.

Contudo, a temática sobre as relações entre cidade e fotografia no Brasil manteve-se até hoje conforme a uma abordagem territorial restrita. Os estudos críticos permanecem voltados a representações regionais, com destaque para as cidades de São Paulo e Rio de Janeiro, além de Porto Alegre e outras capitais com menor frequência. Assim, a análise comparativa sobre a representação das cidades brasileiras não se constituiu como objeto de estudo regular. ${ }^{21}$

Militão ressurge na década de 1970 como autor através da dissertação de mestrado de Boris Kossoy. ${ }^{22}$ No contexto social amplo, a obra do fotógrafo está submetida a outra dinâmica. Talvez pela recorrência de suas imagens urbanas, anônimas muitas vezes, e muito pelo acaso da sobrevivência rara de um conjunto documental significativo de sua produção, sob diferentes formas, reunindo cópias fotográficas, reproduções, documentos textuais etc. ${ }^{23}$ o rol dessa produção de Militão acabou por se constituir em "obra icônica", expressão recorrente para justificar a sua permanência no imaginário coletivo, designativo de reprodução blasé em tantas oportunidades. Surgem assim tomadas como monumento, como reiteração, o que exigirá sua exegese à luz do conceito documento/monumento, como coloca Jacques Le Goff (1988, 1990). ${ }^{24}$

Vamos sumarizar parte do percurso dessas fotografias numa perspectiva mais abrangente, a partir do início do século XX para apontar algumas operações que interessam ao escopo do ensaio: as intervenções sobre a temporalidade dessas imagens. Constituem-se no conjunto como marcos conhecidos de diálogos com a obra de Militão, porém com redirecionamentos e interpretações de longo alcance e permanência pouco questionados. conjunto. É irônico que o gesto de Navas chame a atenção sobre esta estranha luminosidade, pois a produção de vistas urbanas por Militão - enquanto obra visual em fotografia - nunca recebeu comentários quanto à iluminação ao longo da historiografia. Foram tomadas pelo valor de face, como documentos.

17. Embora o ensaio não aborde extensivamente $\mathrm{o}$ tópico, é certo que as diferentes dimensões da memória interagem diretamente com os processos de modelagem identitária. Nesse sentido, apenas Navas, em programação paralela à exposição que será analisada no segmento final, procura estabelecer estratégias para oficina com o público, em visitas à região central da cidade, com produção de registros, conversas, etc.

18. Meneses (2003, p. 30-31). Não adotamos os termos presentes naquela obra - visual, visível e visão, tomando a posição do autor que tais denominações poderiam ser aprimoradas.

19. Autor reinstituído deve-se lembrar, pois apesar do esquecimento por longo período do século XX do fotógrafo, suas imagens mantiveram presença contínua tanto na historiografia sobre a cidade como na imprensa em momentos de comemoração da memória paulistana.

20. Essa coincidência pode ter motivado (como hipótese precária) uma reflexão crítica pouco desenvolvida, reiterativa, sobre a produção imagética de Militão Augusto de Azevedo. Instituído como ícone num primeiro momento na década de 1970 , seriam necessárias quase duas décadas para retomada da obra enquanto objeto problematizado em forma mais regular.

21. Exemplo raro é a tese de 
doutorado de Arruda (2011), publicada com o mesmo título pela Fino Traço (2013).

22. É necessário ressaltar que a produção acadêmica de Boris Kossoy integra esse conjunto mínimo de proposições dedicadas a uma história da fotografia, tomada em seus diversos modos e aspectos, que começa a surgir nos programas de pós-graduação no Brasil ao final da década de 1970. Cf. Kossoy (1978).

23. O acervo fotográfico remanescente de Militão Augusto de Azevedo foi incorporado ao Museu Paulista-USP em meados década de 1990. A decisão adotada de integrar no pacote de financiamento as etapas de aquisição e processamento do conjunto, mediante aporte da Fundação Roberto Marinho, criou situação nova entre nós, estimulando em pouco tempo uma onda de estudos a partir do conjunto documental.

24. Le Goff (1990, p. 535).

25. O termo "vista", corrente ao longo do século XIX, é empregado ainda hoje na historiografia para tratar do tema. É utilizado para designar imagens feitas fora do estúdio, seja na cidade, seja no campo, no domínio da paisagem. As vistas urbanas, enfaticamente edificações e logradouros, realizadas por profissionais para comercialização isoladas ou em conjuntos, ganham mais tarde a forma editorial do álbum com imagens fotográficas, primeira manifestação do livro fotográfico, conforme prática generalizada em muitos países. Esse gênero de vistas, ao final do século XIX, terá alguma centralidade no contexto do cartão postal, fenômeno de consumo de massa com alcance transnacional.

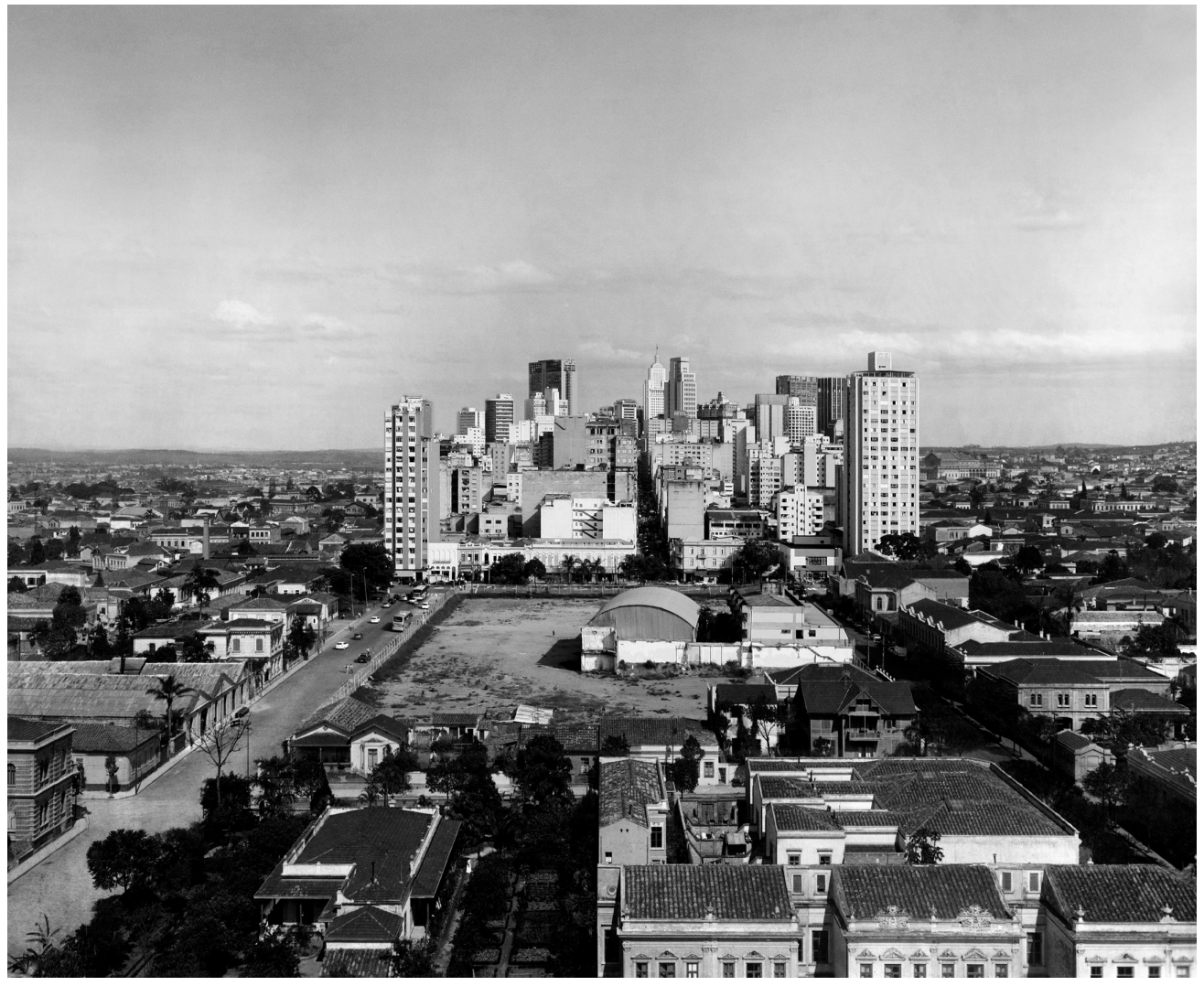

Figura 3 - Marcelo Zocchio, série Repaisagem (2005-20 15 c.) (Largo Coração de Jesus), fotografia preto e branco manipulada a partir de imagens do artista e de Guilherme Gaensly. Acervo pessoal do artista, imagem utilizada na capa do livro Repaisagem (2012).

Como profissional, nas condições possíveis no contexto urbano brasileiro oitocentista, Militão Azevedo atuou no estúdio de retrato, espaço privilegiado de produção de imagens entre 1860 e as primeiras décadas do século seguinte. $\bigcirc$ limite temporal inicial demarca o momento em que a demanda concentrada permite a fixação do profissional num local e o limite oposto indica o surgimento de novas modalidades de produção de imagens, com a fotografia vernacular, a produção amadora, etc., e campos especializados como fotojornalismo e fotografia publicitária. Sob esse recorte, ao longo da segunda metade do século XIX, o fotógrafo profissional é autor social único entre nós, produtor de imagem numa sociedade com pouca expressão das artes visuais, munido de instrumento técnico associado à modernidade.

A produção de vistas - urbanas ou não - chega a delinear um segmento de especialização durante o século XIX. ${ }^{25}$ Como produto, apresenta maior 


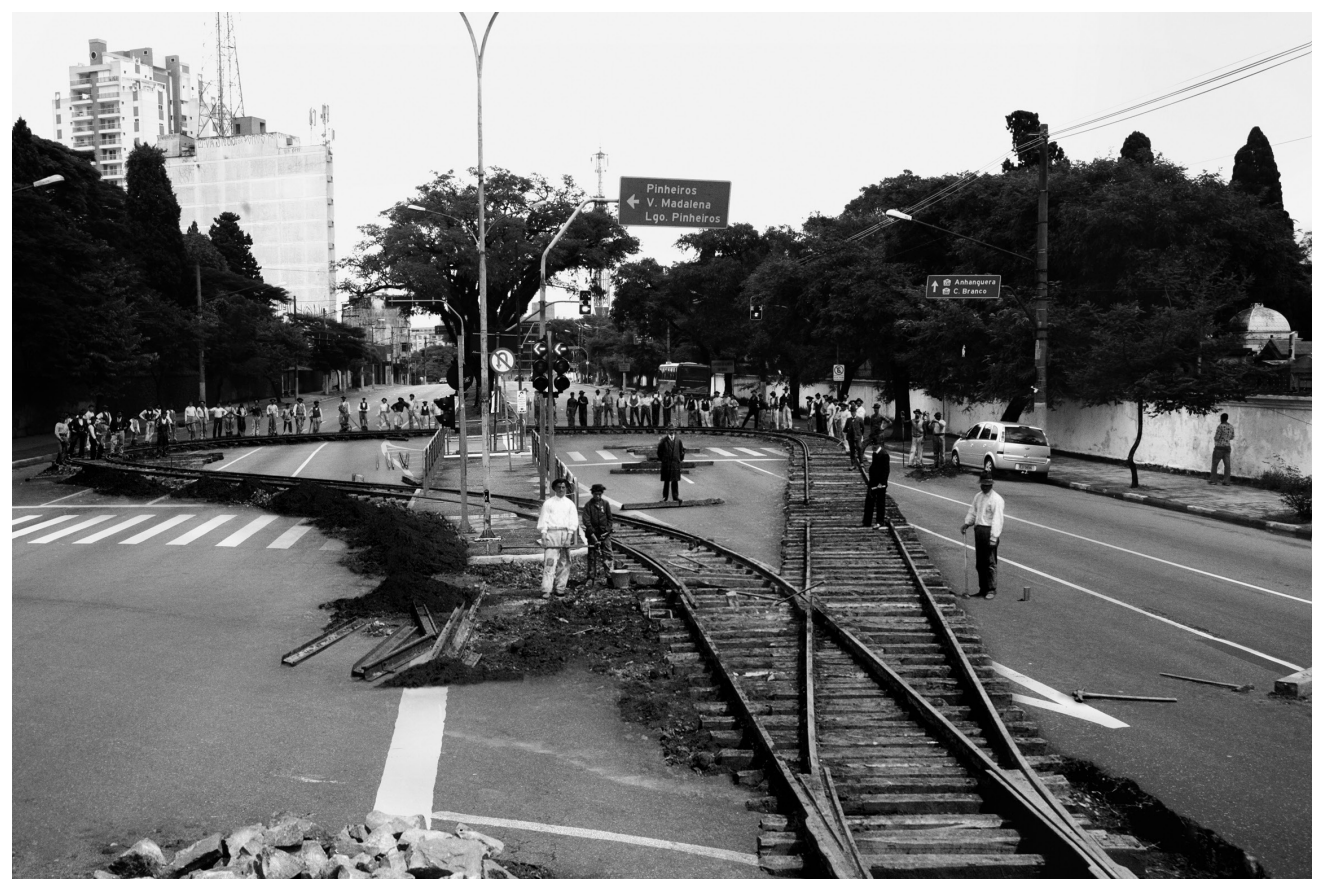

Figura 4 - Marcelo Zocchio, série Repaisagem (2005-2015 c.) (Av. Dr. Arnaldo), fotografia preto e branco manipulada a partir de imagens do artista e de Guilherme Gaensly. Acervo pessoal do artista.



Figura 5 - Marcelo Zocchio, série Repaisagem (2005-2015 c.) (Parque Dom Pedro II), fotografia preto e branco manipulada a partir de imagens do artista e de Vincenzo Pastore. Acervo pessoal do artista. 
26. Para compreender essa dinâmica no quadro paulistano, em escala menor em comparação à capital do Império, cf. Goulart; Mendes (2007).

27. Correio Paulistano (1859, p. 3), com nova inserção em 10 nov. 1859, p. 4. A oferta deve ter despertado algum interesse, pois em outubro do ano seguinte, o mesmo estabelecimento oferece uma "nova coleção" de vistas da Academia de Direito Correio Paulistano (1860, p. 3).

28. O envio de fotos à imprensa, em geral retratos, é corrente desde a década de 1860 em São Paulo e no Rio de Janeiro, por exemplo, como forma de atestar a qualidade da produção. $\mathrm{O}$ uso de vistas da cidade nesse sentido, parece ser o objetivo dos fotógrafos Elwell e Dulley, em junho e julho de 1866 , como registram notas no jornal Correio Paulistano, nos dias 6 de junho e 7 de julho de 1866 , na segunda página destas edições.

29. Annuncios. Correio Paulistano, 22 de outubro de 1863, p. 2.

30. Jesus Christo Müller, profissional, atuando em ambrotipia e fotografia no período, tem a autoria do álbum em questão posta em dúvida por autores como Pedro Correa do Lago (2001) e Eudes Campos (2007). Ambos os autores especulam, embora sem referências a fontes, que o jovem Militão, iniciante no segmento, poderia ter delegado a Müller a comercialização de suas primeiras vistas.

31. Registre-se ainda um "bonito sortimento de vistas photographicas da cidade" para quadros e estereocopos, que é oferecido pela Livraria Garraux, no Largo da Sé, em outubro de 1864 , em anúncio sem informação quanto à possibilidade comercial em centros urbanos com demanda, seja interna, pela existência de um mercado local consistente, seja externa, com a ocorrência de um público de visitantes ocasional ou com a necessidade de remessa para outras localidades. ${ }^{26}$ Assim, por exemplo, em novembro de 1859, o Bazar Paulistano anunciava "vistas fotográficas" da Academia de Direito: "Aqueles srs. estudantes que desejarem levar para seus lares uma lembrança do lugar de sua vida acadêmica, acharão estes lindos quadros mui próprios para tal fim." ${ }^{27}$

O gênero vai valorizar mais o registro das edificações do que o universo da rua propriamente. É oportuno mencionar que essa produção, aqui comentada no recorte paulistano, não foi consistente e exaustivamente estudada pela historiografia brasileira quanto ao período que coincide com as imagens de Militão.

A presença da vista urbana ocorre não apenas como produto em si, como mercadoria, mas também como meio para divulgação da produção de fotógrafos profissionais. ${ }^{28}$ As ofertas de vistas da cidade apresentam forma mais complexa, já em 1863, quando J.C. Müller anuncia na imprensa local "álbum com 30 vistas dos principais edifícios e ruas desta cidade". ${ }^{29}$ A oferta é dirigida diretamente aos alunos quintanistas da Academia de Direito, como lembrança da cidade, ${ }^{30} \mathrm{e}$ parece marcar a introdução, no contexto paulistano, do livro de imagens na forma de álbum reunindo cópias fotográficas.

O mercado local talvez não tenha sido tão promissor para essa novidade. Apenas 13 anos depois, em 1876, o fotógrafo Walter Bradley (EUA, ?-Brasil, 1877), profissional itinerante, anuncia o álbum Lembranças de S. Paulo, em dois volumes. Como o anterior, únicos casos conhecidos de série de imagens da cidade, que precedem o Álbum Comparativo da Cidade de S. Paulo (Azevedo, 1887), as imagens de Bradley não deixaram remanescentes. ${ }^{31}$

Esse gênero de produção, em seus primórdios, é pouco estudado pela falta de conjuntos significativos em acervos locais, que permitam ao menos (re)articulálos. ${ }^{32} \mathrm{~A}$ isso, merece menção outro aspecto "característico" da historiografia da fotografia regional sobre o período: o seu alheamento a uma cultura que faz uso do desenho e dos recursos à impressão mecânica. Esse traço parece surgir como dano colateral de uma historiografia sobre fotografia que demorará a ser pensada no contexto maior da cultura visual.

Sem procurar estender o ponto, mas aqui num exemplo central para o período, seria relevante mencionar a presença de dois agentes significativos para a cultura visual local. Primeiro, de Jules Martin (França/Moustiers, 1832 São Paulo, 1906), ${ }^{33}$ que por meio de sua Imperial Litographia faz uso jornalístico 
de estampas sobre eventos locais; segundo, o surgimento da imprensa ilustrada, marcada pela crônica urbana e pelo crítica política associada ao humor, em revistas editadas por Angelo Agostini (Itália, 1843-Rio de Janeiro, 1910), como Cabrião (1866-1867).

Em 1887 é lançado pela Photographia Americana, de Militão Azevedo, o Álbum comparativo da Cidade de S. Paulo. Artigo curto publicado na imprensa, no Correio Paulistano, em agosto daquele ano, deve ser visto como um marcador que avalia com atenção a iniciativa. Talvez primeira resenha local sobre uma publicação fotográfica, serializada, o texto é direto: "É o progresso de São Paulo fotografado", comentando os registros da cidade entre 1862 e 1887 ali reunidos. articulista anônimo aponta o valor da publicação "para se verificar o progresso da província" como "fonte de estudo" pari passu às estatísticas. ${ }^{34}$

Embora sem registro seguro, a publicação tem tiragem de algumas dezenas de exemplares. Reúne imagens realizadas em 1862 e em 1887, aquelas integrando os primeiros momentos da formação técnica do fotógrafo, por vezes comercializadas isoladamente ao longo do tempo, ${ }^{35}$ de forma secundária à produção de retratos do estúdio, e as últimas, derradeiros registros da cidade feitos por Militão. ${ }^{36}$ A edição do álbum marca ainda o fim de sua prática profissional.

A década de 1890 será momento marcante para a cidade: crescimento populacional explosivo no quadro do ciclo econômico do café e uma industrialização nascente. As mudanças urbanas, geradas por alteração de padrões urbanísticos que procuram atender a demandas de transporte e saúde pública, bem como a implantação de novos serviços como distribuição de energia elétrica são bem conhecidas. Abre-se um período, no que toca às imagens da cidade, de introdução de novas modalidades e condições técnicas como o registro documental da cidade em base mais regular para as administrações estadual e municipal, embora de uso restrito, ${ }^{37}$ e o comércio de estampas, agora integrado ao surto do cartão-postal, principal veículo de circulação interpessoal de imagens por algumas décadas.

Militão deixa de ser uma referência rapidamente. Em parte, por sua aposentadoria, em parte, pelo então fluxo imagético explosivo com novos padrões de visualidade em postais ou vistas por profissionais como Guilherme Gaensly (1 843-1928). Suas imagens, no entanto, estão presentes anonimamente em coleções e nas publicações que surgem no início do século XX. São objeto também de circulação entre os primeiros colecionadores que se dedicam à história da cidade, muitos estimulados pelas comemorações do I Centenário da Independência que se aproxima. ${ }^{38}$ autoria das imagens. Correio Paulistano (1864, p.4).

32. Nota de agradecimento pelo exemplar enviado por Bradley é publicada em $A$ Província de São Paulo, de 30 de agosto de 1876 , à página 2 , configurando, porém, um registro único sobre a iniciativa. Sob o título Photographias de S. Paulo, o articulista comenta serem dois conjuntos de vistas urbanas, cada um em livro na forma de carteira, provavelmente em edição sanfonada, com 12 imagens cada, relacionando os logradouros e edifícios em destaque.

33. Martin, em paralelo a essa prática, é desde o primeiro momento de sua atuação em São Paulo em 1878 um comerciante de vistas fotográficas da cidade. Cf. Goulart; Mendes (2007) e Mendes (2004).

34. A velha e a nova cidade de S. Paulo. A Província de S. Paulo, 11 de agosto de 1887, p. 2. Apud Mendes (2013, p. 298-299).

35. Exemplo disso é a imagem da Rua Direita em 1860, talvez um dos registros mais significativos do cotidiano urbano oitocentista e seu comércio central, com estabelecimentos e suas mercadorias expostas nas portas. É relevante notar a legenda, nesta edição em formato carte-de-visite, que sob o título principal S. Paulo destaca o nome do logradouro em português, alemão, francês e inglês. Embora não datada, o uso dessa imagem então está mais orientado para a difusão de um registro contemporâneo da cidade do que por seu valor como eventual reminiscência histórica. O item integra a coleção MAA, do Museu Paulista-USP, sendo reproduzida em Goulart e Mendes (2007, p.82-83).

36. Existem ocorrências raras de outros álbuns ilustrados por Militão como Vistas da 
Estrada de Ferro de São Paulo em 1865, mas são edições com tiragem única ou reduzida. É mesmo possível questionar, nestes casos, a autoria do formato álbum, editado efetivamente pelo fotógrafo, ou mesmo a contemporaneidade da produção do álbum com o período das fotos. Um exemplar do álbum citado integra o acervo da Biblioteca Mário de Andrade (BMA/ SMC/PMSP), com imagens isoladas também presentes no acervo do Museu Paulista-USP. Estas imagens foram objeto de estudo no livro São Paulo Railway: álbum estrada de ferro (Magma Cultural, 2010), com textos de Gino Caldatto Barbosa e Marjorie de Carvalho F. de Medeiros.

37. Esses conjuntos de registros técnicos, nem sempre preservados na integridade, associados a documentações técnicas gráficas ou textuais como relatórios de circulação restrita, terão papel central nas décadas de 1980 e 1990 quando ocorre uma reconfiguração do conjunto de registros remanescentes sobre a cidade, com acesso público crescente. $O$ processo tem lugar no reordenamento de antigos acervos, mas em especial, com algum destaque, em novas instituições de memória, nas esferas pública ou privada, como o Museu de Energia e Saneamento ou o Instituto Moreira Salles.

38. Esse marcador temporal surge com destaque no panorama aqui delineado. Além do crescente envolvimento de interessados em história nacional, enfaticamente pelo período colonial, há engajamento do Estado em suas diversas estâncias para as comemorações. É fenômeno recorrente no contexto imediato, marcado pelo uso da fotografia cada vez mais intenso, estimulando um boom editorial. Ações similares, importantes para o segmento da memória local, terão lugar na década de 1950 quando da comemora-
É nesse contexto que se registra procedimento decisivo para a percepção a longo prazo da obra de Militão. A ação, no início da década de 1910, resulta da aproximação do político Washington Luís Pereira de Sousa (Macaé, 1869-São Paulo, 1957) e do fotógrafo Aurélio Becherini (ltália, 1879-São Paulo, 1939).

Washington atua como deputado estadual em São Paulo desde 1902. Anos antes fora vereador em Barra Mansa (RJ), onde começara carreira como promotor público. Por seis anos a partir de 1906, exerce o cargo de secretário estadual de Justiça de São Paulo. Muito provavelmente data do período o contato com Becherini, que após atuar com estúdio de retrato é um dos fotojornalistas mais conhecidos num momento em que a imprensa diária dá passos mais consistentes para o emprego da fotografia. A cobertura dos principais eventos oficiais se dá então em espaço próximo. O Palácio do Governo e as secretarias de Justiça e de Agricultura, espaços administrativos centrais no período, ficam a poucos metros de distância, ao redor do Pátio do Colégio, o que deve ter permitido a convivência regular.

Washington Luís, advogado de formação, dedica-se ativamente à pesquisa histórica, com particular interesse sobre o período colonial. Em paralelo à ałuação como deputado estadual, frequenta o círculo de historiadores e interessados no tema. Em 1903 edita ensaio que dará origem, em 1918, ao livro Capitania de São Paulo, governo de Rodrigo Menezes (Garraux), e nesse mesmo ano lança Na capitania de São Vicente ([s.e.]). Note que o autor já responde pela prefeitura de São Paulo desde janeiro de 1914. Esse interesse talvez explique o apoio imediato no mesmo mês de sua posse a despacho para publicação da transcrição das atas da Câmara Municipal cobrindo todo o período colonial, fundamental fonte de pesquisa da história local.

Não importa agora como o encontro entre o gestor/historiador e o fotógrafo se deu. ${ }^{39} \mathrm{O}$ fato é que no mesmo ano de início do mandato registrase a organização do Álbum comparativo da Cidade de S. Paulo: 1862-18871914, em dois volumes. Como na publicação de Militão, trata-se de um álbum de fotografias originais. Desconhece-se tiragem mais extensa, salvo o conjunto remanescente incorporado, provavelmente, ao final da década de 1930 ao acervo municipal, aos cuidados da hoje Biblioteca Mário de Andrade, na atual seção de Obras Raras. Outros três álbuns, em dois volumes, integram o mesmo conjunto. ${ }^{40}$ Destes, chama a atenção a designação clara - como organizador - ao "Exmo Sr." prefeito Washington Luís, presente nas segunda e terceira publicações. A última edição apresenta a variante "organizado por autorização" do senhor prefeito. 
Editado assim entre 1914 e 1919, conforme as datas estampadas nas capas, o conjunto reúne quase 500 imagens, reproduzindo boa parte de toda iconografia paulistana produzida até o final do século XIX conhecida no período. ${ }^{41}$ Em agosto de 1919, Washington Luís deixa o cargo, preparando-se para a campanha à presidência do Estado de São Paulo.

Mas que gesto primordial marca essas edições? $\bigcirc$ álbum, editado em 1887, tem uma estrutura que vai além da ênfase comparativa, como é normal pensar. Ainda que a designação seja direta no título, a sequência de 60 imagens no formato álbum, com imagens isoladas coladas em cada página, parte de uma introdução pouco usual: um encadeamento de três fotografias, tomadas do alto de torre no Jardim da Luz, em direção ao centro da cidade. Aos pés da imagem panorâmica, dividida em três páginas, o que dificulta a leitura para uma plateia acostumada com modalidades posteriores de discurso visual, surge a principal estação ferroviária da cidade em extenso registro, mas ainda instalada em edifícios de pequeno porte que desapareceriam ao final do século. Há algo aqui que o leitor, de gerações seguintes, pode não atentar. $\bigcirc$ local é porta de comunicação direta com o exterior e parte do país, através da ferrovia que liga a cidade ao litoral, substituindo gradativamente as comunicações terrestres a cavalo ou em carruagens que marcaram por décadas o entorno paulistano. As imagens iniciais registram locus de chegada e partida privilegiado para a modernidade que se estabelece.

A partir desse ponto, em suma, as imagens avançam para o centro da cidade, a partir do qual um conjunto extenso de pares de imagens, feitas entre 1862 e 1887, confrontam ruas e largos. O segmento final, ainda que integre imagens de ambas as datas, faz um percurso em espiral, rumo a regiões periféricas, entre tecido urbano e outro, descampado, sem caracterizar uma ocupação rural efetiva, até terminar com registro às margens do Rio Tietê. $\bigcirc$ último núcleo retoma a abordagem sincrônica, compara por vezes momentos entre os dois anos-limite, mas utiliza para isso sequências, e não imagens isoladas.

Militão articula nesse discurso visual estrutura relativamente complexa. A vista do alto da paisagem urbana é quase um prenúncio de prática que anos depois marcará esse gênero editorial. ${ }^{42}$ Em parte, como meio para obter uma visão totalizadora, e depois como procedimento visual introduzido pela imagem fotográfica na cultura visual do século XX. ${ }^{43} \bigcirc$ núcleo comparativo, que será tomado como marca única de Militão, é estruturado ainda como parte de percurso pela área central, ao redor de poucas quadras, que reúne edifícios do governo ou da Igreja Católica, estes com menor expressão no tratamento visual dado. Por fim, o último núcleo realiza o trajeto rumo ao espaço periférico da cidade, seus territórios ção do quarto centenário da cidade de São Paulo (fenômeno retomado, com similaridade e especificidade local, em outros centros urbanos como Rio de Janeiro em suas efemérides), e 50 anos depois nos eventos associados aos 450 anos da fundação da capital paulista. Acompanhar a presença de imagens de Militão nesses ciclos seria um estudo oportuno para um mapeamento das ressignificações contínuas desse repertório.

39. Ignorado completamente pela historiografia da fotografia no tocante ao papel representado na ação relatada, Washington Luís, junto com Aurélio Becherini, - e talvez com maior relevância por seu duplo papel de historiador e gestor municipal - deve ser visto como coautor dessa apropriação das imagens de Militão Azevedo, peça-chave no redirecionamento da interpretação da obra por longo período. Sobre Becherini, cf. Fernandes Jr (2009).

40. Sobre os álbuns em questão, bem como um resumo do conjunto iconográfico nos formatos álbum de fotos e álbum impresso sobre a capital paulistana entre as décadas de 1880 e de 1950, cf. Lima; Carvalho (1997), obra que será comentada adiante.

41. Certamente, desconsiderando a produção de registros fotográficos para diversas unidades dos governos estadual e municipal a partir de meados da década de 1890 e suas concessionárias, o conjunto, ao qual se somariam outros esforços como a coleção que se forma lentamente no que hoje é conhecido como Museu Paulista, na gestão Afonso Taunay, entre 1917 e 1946, constitui o núcleo primordial da documentação fotográfica sobre (e da história da fotografia em seu todo na) a cidade de São Paulo. A virada para o século XX apresenta uma 
dinâmica ampliada de produção e circulação de imagens, com novas modalidades, que modifica plenamente o quadro geral. Sobre o estudo desse momento, a pesquisa, acadêmica ou não, tem avançado lentamente em suas ações.

42. Esse aspecto é comentado por Íris Araújo (2010), em artigo que resume seu doutorado (2006, publicado em 2010), embora sem maior desenvolvimento nessa análise. Cf. Araújo (2010).

43. A tomada do alto parece se impor no contexto urbano adensado das cidades maiores, mas a oferta de câmeras cada vez mais compactas estimulará esse mergulho. Os registros plongée e contra-plongée permitiam explorar perspectivas e estabelecer estruturações visuais inesperadas.

44. Tal ação se revela já no primeiro álbum organizado pelo Sr. Prefeito, que - agora introduzindo imagens para os anos de 1862, 1887 e 1914, nem sempre nessa regularidade -, cria um frenesi imagético, que exige do leitor um conhecimento profundo para rearticular espacialmente os locais registrados. O conjunto de imagens, embora legendado e acompanhado por mapa inicial da cidade em diferentes momentos, está distante de um panorama visual, modelo ao qual Militão se atém. O termo frenesi aqui utilizado pode ser tomado como um comentário a um momento de produção visual fim de século quando se agudiza então, sintoma de novas formas da visualidade, o deslocamento da ênfase sobre as imagens isoladas para o fluxo visual propriamente.

45. Seria fácil argumentar que isso nada mais é que a expressão do estatuto cultural da fotografia então, do lugar reservado aos agentes de produção e circulação de fronteiriços, e parece articulado com menor rigor, reflexo provável até da indefinição de papéis dessas áreas na cidade em desenvolvimento.

que acontece agora, 30 anos depois, através da edição do gestor municipal e do fotógrafo (Becherini)? Tudo que é sincrônico, digamos, tudo que partilha de contexto próximo, conforme a estruturação delineada, em 1887, por Militão, é eliminado. O comparativo se impõe. $\bigcirc$ gesto de aproximar tomadas de edificações ao longo de 25 anos poderia ser interpretado na edição original como forma de destacar a mudança, criando um afastamento temporal passadopresente, na busca de tornar evidente a transformação espacial, mantido, contudo, um "emolduramento", um percurso, que articula o conjunto. Os álbuns editados na década de 1910 não permitem mais, em sentido contrário, pensar a cidade como momentos inter-relacionados de uma paisagem. Essas novas publicações subordinam cada local ao vetor temporal. Isolam os espaços, tornando-os intercambiáveis. ${ }^{44}$ Submetem o espaço a um tempo estilhaçado, mas paradoxalmente tomado como coerente, linear.

Essa marca - comparativismo absoluto, digamos - acabará por obscurecer qualquer outra possibilidade de interpretação da obra de Militão. Ressalve-se que aqui as imagens não surgem creditadas, nem as de Militão, nem as complementares, realizadas por Becherini em seu tempo. O álbum original, gesto autoral, como a resenha na imprensa em 1887 indica, dá lugar a meros repositórios de imagens. ${ }^{45}$

A essa operação seria oportuno aproximar outras formas de apropriação que exemplificam novos agenciamentos no uso reiterado dos registros de Militão. Uma delas toma corpo em locus privilegiado para a história - o Museu do Ipiranga, edificado como monumento à Independência nacional. A gestão iniciada em 1917 pelo historiador Afonso de Taunay (Florianópolis, 1876-São Paulo, 1958), que será eleito para a Academia Brasileira de Letras ao final da década de 1920, desenvolve entre seus projetos a concepção cenográfica de espaços do edifício, bem como a produção de uma iconografia histórica. Na ausência de um conjunto pictórico "suficiente", digamos assim, ao seu propósito naquele momento, Taunay encomendará novas obras, pinturas em especial. Para isso conta com documentação histórica textual e iconográfica reconhecida nas décadas iniciais do século, da qual as imagens de Militão fazem parte. ${ }^{46}$ Aqui a imagem fotográfica será intensamente utilizada como fonte, mas editada, recortada, configurando "registros" que apresentem e caracterizem espaços e costumes no passado. Um dos artistas com obras no acervo do museu, José Wasth Rodrigues (1 891 1-1957), ganhará grande visibilidade anos depois ao circular a série de postais São Paulo Antigo (Edições Marfim, [1954]), com aquarelas coloridas a partir de registros da cidade realizados 
por Militão, entre outros fotógrafos. Item popular por décadas, essa modalidade de imaginação histórica terá grande recorrência. ${ }^{47}$

$\bigcirc$ projeto museológico de Taunay, orientado para as comemorações do centenário de 1922, inclui ainda episódio peculiar, em que as mesmas imagens integram a produção de instrumental de difusão relevante: a maquete de São Paulo em 1841. O historiador não parece preocupado, embora faça uso corrente dessas fontes, em pensar a estruturação de acervos fotográficos e seus instrumentos de acesso; estes permanecerão na forma de velhos álbuns, sem tratamento de informação. Seus autores, seus agenciamentos originais esmaecem, submetidos à cenarização historiográfica do Taunay gestor. ${ }^{48}$

No entanto, as imagens foram peças-chave para a construção da grande maquete de São Paulo antigo, até hoje preservada, com destaque na expografia remanescente do período. Para o projeto, promove-se a vinda ao Brasil do modelador holandês Henrique Bakkenist. Ponto curioso é que Taunay tenha decidido reconstituir a configuração urbana em 1841, mais de duas décadas antes dos primeiros registros fotográficos, momento de parcos registros visuais de outra natureza. $\bigcirc$ marco inicial do projeto era 1822, porém a ausência de dados motivou a alteração. A decisão é justificada, aparentemente, por ser desse ano a edição de planta da cidade, com levantamento cadastral parcial, referência significativa para a proposta. Ao empregar fotografias, outra referência de mesmo grau para a operação, realizadas 20 anos depois, Taunay assumia riscos e expunha os mecanismos aplicados nas pinturas encomendadas. Essas ações se realizam com prazer ao longo da "reta" do tempo. A planta base para 1841 é incompleta, exigindo recorrer a outra posterior de 1847. A opção pelo ano de 1841, num comentário em tom de blague, pareceria mais bem justificada se lembrássemos de ser o mesmo da coroação de Dom Pedro II, nosso soberano ilustrado. Uma última ação, por gerações posteriores, trouxe nova colaboração nessa construção. A maquete original com suas edificações e ruas era completamente branca; em 1984, a direção do Museu Paulista decidiu colorir o conjunto. Instrumental relevante para expografia, hoje em especial ao integrar-se ao campo de modelagem gráfica, essa primeira virtualização em grande escala (cerca de 6 x 6 metros), como recurso expográfico, é até agora episódio pouco estudado, embora contundente produto do campo historiográfico local em suas raízes remotas.

Militão e a história da fotografia se encontrarão por fim na década de 1970. Boris Kossoy (São Paulo, 1941), pesquisador que participa do início da conformação do campo de estudo, apresenta em 1978 sua dissertação de mestrado sobre os registros da cidade reunidos no álbum de 1887. A comunhão entre tema do projeto e estabelecimento de área de conhecimento especializado imagens. É contudo um traço de apagamento de agentes e de estruturas de produção que convive com um momento de explosão de práticas visuais de alcance social inimagináveis, a exemplo da imprensa ilustrada, então em novo ciclo expansivo, ou mais ainda na introdução do cartão postal, objeto de troca social complexa, que apenas a aproximação com fenômenos posteriores como as redes sociais atuais permite hoje uma primeira compreensão do impacto ao observador não especialista.

46. O caso ganhou espaço para pesquisa na década de 1990 a partir da gestão Ulpiano Toledo Bezerra de Meneses, em especial na comemoração do centenário da edificação. Sobre o tema, no recorte que interessa ao presente ensaio, cf.: Carvalho; Lima (1993). Para uma apreciação mais ampla, num panorama que dá conta das pesquisas posteriores, veja o registro audiovisual relativo ao simpósio Affonso de Taunay e o Museu Paulista: cem anos de um projeto de memória (1917-2017), realizado no Museu Paulista, nos dias 29 e 30 de novembro de 2017 (vídeos disponíveis em: <http://iptv.usp.br>. Acesso em: 2 jul. 2018).

47. Algo acessório ao ensaio, mas evidência do grau de mobilização que esses objetos podem articular, está no fato que exemplares da série editada em postais trazem estampado no verso texto sobre campanha para arrecadação de fundos em prol da candidatura de Plínio Salgado à presidência da República em 1955.

48. Como referência, veja o vídeo Maquete - A cidade de São Paulo em 1841 (produção Base 7, 2015, 5'34”), disponível em: <http://vimeo. com/136064820>, Acesso em: 6 jul. 2018. 
49. Cf. Kossoy, 1978, Resumo, n.p.

50. Cf. Carvalho (1995).

51. Essas reproduções foram realizadas em sua maior parte por Aurélio Becherini para a organização dos álbuns comissionados por Washington Luís, cujo confronto entre negativos de reprodução e cópias vintage permite confirmar a interrelação entre conjuntos custodiados na BMA e Casa da Imagem. Existem cópias vintage nos álbuns em questão (BMA), nas fichas de consulta (Casa da Imagem) e em seriações com montagens distintas (BMA) provavelmente estruturadas na década de 1930 ou seguinte.

52. Entre elas, cf. Azevedo (1981) e São Paulo (1982), que se constituem como livros de imagem, reproduções integral ou parcial dos álbuns anteriormente comentados.

53. A quase totalidade de autores voltados ao tema será formada por arquitetos dedicados à história da cidade, como Benedito Lima de Toledo (1934-2019) e Carlos Lemos (1925), por exemplo, o que pode caracterizar a ênfase na análise como fonte documental para história urbana. Kossoy, ele mesmo, é arquiteto de formação, mas é possível apontar que vários pesquisadores que atuam nas interfaces das artes visuais, estética, arquitetura e comunicação nas décadas de 1970 e 1980 têm essa origem comum, provável consequência da constituição tardia localmente das graduações e pós-graduações em artes e comunicação. está explícita no resumo: "A obra de Azevedo representa um capítulo importante a ser inserido numa futura história da fotografia no Brasil. Com esta pesquisa, espero, contribuir para essa história." 49

É necessário lembrar que as imagens de Militão, mergulhadas naquele conjunto imagético constituído no início do século XX, têm presença contínua em momentos que antecedem as comemorações do quarto centenário da cidade, em 1954. São registros correntes na imprensa de então como ilustração de apoio, notas comemorativas, evocadoras do pitoresco, do antigo e do moderno, par conceitual recorrente em toda manifestação bibliográfica integrante do boom editorial que então se realiza. ${ }^{50}$ Seria oportuno lembrar que esse conjunto de imagens já está no período incorporado ao acervo de instituições locais como Museu Paulista-USP e unidades do então Departamento de Cultura (PMSP), a saber: a Biblioteca Mário de Andrade e o setor de Iconografia, abrigado no Arquivo Histórico Municipal, primeiro acervo fotográfico local aberto ao público, que passará por vários arranjos administrativos até integrar a estrutura da atual Casa da Imagem (SMC/PMSP). Correspondiam tanto a edições originais do álbum de 1887 como também fotos isoladas e incluíam ainda nesse repertório reproduções posteriores, realizadas a partir da década de 1910,51 ocorrência enviesada que garantiu preservação de registros tão distantes no tempo.

A década de 1970, momento da fala de Kossoy, é marcada pelo início de um longo processo de confluência de ações em que instituições serão reconfiguradas ou organizadas para cuidar da memória da fotografia no Brasil, novo enquadramento a que se submetem as mesmas imagens. $\bigcirc$ que interessa aqui é destacar a reiterada ocorrência de publicações dedicadas a Militão que the deram visibilidade como autor, ${ }^{52}$ que o recuperam em nova circunstância. Isso se deu, como indica o título da obra de Kossoy, na análise do conjunto como fonte documental, estudos distantes dos aspectos discursivos, da narrativa visual propriamente. ${ }^{53}$

Com o estabelecimento em bases mais regulares de programas de pósgraduação em artes e em comunicação, junto com os programas em arquitetura e em história, a pesquisa acadêmica sobre fotografia, em seus diversos aspectos, tomou corpo na década de 1990. O momento coincidiu com a incorporação do conjunto de imagens remanescente do estúdio de Azevedo ao Museu Paulista, ampliando de forma significativa o repertório visual e textual disponível para consulta.

Alguns projetos de pesquisa marcam as primeiras interpretações sobre a produção editorial de állbuns de vistas urbanas no largo arco entre as décadas de 1860 e 1950, como os mestrados de Lima e Carvalho (ambos em 1995), reunidos 
no livro Fotografia e cidade (1997). ${ }^{54}$ Pela primeira vez, esse extenso conjunto é visto em sua integridade, embora a edição final destas pesquisas, no formato livro, privilegie a metodologia estatística para análise visual em detrimento do percurso histórico, reiterações, etc. Outras abordagens ganhariam espaço como Grangeiro (1993; 2000), Cavenaghi (2000), Leite (2002), Baldin (2006) e Araújo (2006; 2010).

Além do destaque da obra de Lima e Carvalho, é no campo da Antropologia que tem lugar a contribuição de estudos de Fraya Frehse (São Paulo, 1971), entendidos como uma "antropologia da rua" a partir das vistas urbanas paulistanas do século XIX. Esses ensaios problematizam o moderno presente naquelas imagens ${ }^{55}$ e permitem estabelecer novas aproximações. Apenas para citar uma de suas obras, destaque-se 0 da rua: o transeunte e o advento da modernidade em São Paulo (Edusp, 2001).

Finalizando esse balanço, seria oportuno lembrar que os estudos em arquitetura e urbanismo que tomavam como referência o conjunto documental gerado por Militão Azevedo tiveram continuidade nas gerações seguintes a de Lemos e Toledo. E, possivelmente, podem revelar novas percepções subsidiárias. Um exemplo é obra de Eudes Campos, mas não sua volumosa tese de doutorado Arquitetura paulistana sob o Império (1997, FAU-USP), cuja aferição extensiva entre fontes imagéticas, gráficas e textuais permitiu avaliar os registros do início da década de 1860. Seu artigo, publicado nos Anais do Museu Paulista (2007), exige atenção, pois põe em questão uma interpretação recorrente desde o início do século passado, que via ali, naquelas imagens primevas, uma paisagem estagnada, "colonial". Agora Campos, pouco a pouco, em especial no tocante ao espaço público, faz notar que o panorama visual registra ações e configurações sobre a cidade e seu espaço físico em si novas e indica um espaço em estruturação, ainda que de forma lenta, reiterativa, muitas vezes sofrendo prejuízo por se dar tal processo em quadro econômico precário e, principalmente, em meio a uma transição de métodos construtivos e técnicos. Enfim, o que parece velho, desgastado, é ainda novo! Não obstante, o autor parece se confundir muitas vezes no emprego dos termos novo e moderno.

percurso exposto, embora muito focado no registro culto, ${ }^{56}$ permite estabelecer marcadores ao longo do trajeto em que a obra de Militão percorreu. A partir da cisão, estabelecida na década de 1910 por Washington Luís e Aurélio Becherini, a estrutura do álbum de 1887 deu lugar a uma nova obra, estruturada unicamente por uma ação que desarticula passado e presente de seus contextos para estabelecer um futuro de mudança permanente. Subjuga a historicidade dos espaços, veda a visão sobre o campo off (extraquadro), prejudicando, ainda que não intencionalmente, outros modos possíveis de olhar as imagens da cidade.
54. Esta publicação e as seguintes, mencionadas no mesmo parágrafo, foram incorporadas à bibliografia final.

55. O mestrado de Iris Morais Araújo (2000) aponta nessa direção, mas a ênfase está em confrontar as imagens com os textos do fotógrafo presentes em cartas e anotações, que integram o conjunto sob a guarda do Museu Paulista, produzidos em parte após o encerramento da atividade profissional. Esta nova condição e o contexto republicano parecem tensionar as rememorações do fotógrafo.

56. Para não deixar dúvida, registro culto como referência à produção acadêmica, embora seja possível propor estudos similares, extramuros e mesmo no recorte vernacular. Apenas para complementar o breve quadro de referências, cite-se entre as obras produzidas fora do campo acadêmico, mas ainda próximo: LAGO, Pedro Correa do. Militão Augusto de Azevedo. São Paulo: $\mathrm{Ca}-$ pivara; Contracapa / IRB, 2001; Militão Augusto de Azevedo. São Paulo: Cosac Naify, 2012 
57. O termo campo off, embora apresente variações, decorre, primeiro, da experiência cinematográfica, embora seja claramente aplicável a qualquer discurso visual (e mesmo verbal). Ele aponta para a noção do que é externo ao enquadramento narrativo: um olhar off, por exemplo, um relação entre campos visível e não, entre quadro e fora de quadro. Ao longo do século XX foi trabalhado de formas passiva (o palco italiano, por exemplo, que implica em um ponto de vista único, do espectador) ou ativa (como quando um personagem se dirige para a câmera ou interage com elementos fora de quadro), em exemplos elementares do conceito.

58. Recorre-se aqui, indo na mesma direção, à colocação similar, recorrente em apresentações de Frehse, como a recente palestra $A$ (não-) presença negra nas ruas paulistanas da fotografia de Militão, realizada no Museu Paulista-USP, em 24 de maio de 2018 (disponível em vídeo em http://iptv.usp.br. Acesso em: 25 maio 2018). Seria oportuno apontar, como fica evidente na palestra, a contribuição de Frehse ao estabelecer uma metodologia que procura dar conta de uma interpretação mais complexa, interligada, da história do desenvolvimento urbano da cidade, do meio fotográfico e das representações em jogo.

59. Benedito Duarte trabalhou com o conjunto remanescente organizado por Aurélio Becherini, incorporado mais de duas décadas depois ao patrimônio municipal. O processo de incorporação dos conjuntos de álbuns às unidades atuais da Secretaria Municipal de Cultura, sucessora do Departamento de Cultura, demanda, contudo, um rastreamento preciso.

60. Uma nota merece regis-
Depurado de qualquer contexto de historicidade do registro original, o procedimento parece se estabelecer como elemento homogeneizador do urbano, da "vista urbana". Reificando o construtivo, nada que fique fora desse foco pode existir. Apenas eixos temporais verticais, em cada ponto, paralelos: entenda-se assim a ausência do campo off, ${ }^{57}$ pois os espaços não se comunicam entre si, apenas apresentam-se como vetores de tempo próprio, o que pode explicar a redução de interesse sobre o elemento humano, sua presença acessória naquelas imagens.

Essa "percepção comparativa intensificada" que passa a operar constitui um traço identificador da produção imagética sobre a cidade ao longo de várias gerações paulistanas. Essa ocorrência não é usual no repertório imagético de outras cidades brasileiras ${ }^{58} \mathrm{e}$, ainda que ocorra aqui aparentemente em segundo plano, é estratégia poderosa como gesto estruturador e alienante.

Apenas para ilustrar a extensão dessa prática, Benedito Junqueira Duarte (Franca, 1910-São Paulo, 1995), fotógrafo e organizador, na década de 1940, do acervo fotográfico do Departamento de Cultura, hoje abrigado na Casa da Imagem, unidade da Secretaria Municipal de Cultura, empregou de início o "conceito" comparativo na ordenação inicial das imagens. Como ele operou diretamente a partir de fotografias que remetiam aos álbuns da década de 1910, repetiu o mesmo gesto, aderindo assim à origem histórica dos registros. ${ }^{59} \bigcirc$ arquivo emula o "álbum do Sr. Prefeito". O modelo comparativo foi assim naturalizado, incorporado à forma de organização do acervo, desvinculado de dados de origem, autoria, etc. Nele, acesso às imagens e topologia de guarda se confundem. Nem os instrumentos de pesquisa permitiam, por décadas, reconstituir as séries originais, situação que permanece nos conjuntos agora custodiados no Museu da Cidade de São Paulo e na Biblioteca Mário de Andrade.

O mesmo percurso permite, dentro do quadro limitado do presente ensaio, caracterizar a obra de Militão como parte de uma tradição visual local estabelecida ao longo da primeira metade do século passado. Sua permanência em momentoschave de reelaboração de memória local e nacional, como o centenário da Independência ou o quarto centenário paulistano, é exemplo em registro maior. Sua recorrência banalizada, na memorabilia associada a eventos locais ou nas mostras, de origens as mais diversas, sobre passado urbano, retomadas a cada aniversário da cidade, é o contraponto de reafirmação. Indo além, o breve panorama em análise ilustra ações diversas, apropriações e leituras que reforçam a ideia da tradição como construção viva, reiterada ou problematizada por gerações. ${ }^{60}$

É oportuno citar Eric Hobsbawn, coorganizador de The invention of tradition (1983): 
[...] restored or invented tradition refers to a "set of practices, normally governed by overtly or tacitly accepted rules and of a ritual of symbolic nature which seeks to inculcate certain values and norms of behavior by repetition which automatically implies continuity with the past". ${ }^{61}$

A seu modo, a obra de Militão acabou por ter papel privilegiado nesse processo, conforme esboçado no percurso apresentado, mas é possível postular que menos pelos referentes registrados e mais pelo modelo visual com foco na mudança em si conforme os agenciamentos posteriores a redefiniram.

Imagens tomadas como história: presente e passado foram assim submetidos a ações, estabelecendo um continuum não pela forma visual, mas pelo processo que permitiu sua associação com o rótulo progresso. Construídas em níveis crescentes como documentos/monumentos, essas imagens constituem elementos poderosos entre outros mobilizados na produção do imaginário paulistano ao longo do século XX.

\section{RESTAURATIVA, REFLEXIVA: ESPAÇO-TEMPO EM ELABORAÇÃO}

Entre os autores recentes, com contribuição crítica para uma antropologia do tempo, é Svetlana Boym, em The future of nostalgy (2001), que apresenta conceitos adequados para compreender algumas das ações realizadas sobre as imagens de Militão Augusto de Azevedo. Boym propõe dois modos de nostalgia: uma nostalgia restaurativa, centralmente voltada para estabelecer reiteradamente uma condição perdida, e outra reflexiva, consciente, que, em vez de transformar-se em um fim, revela-se uma passagem.

Parece ser possível entender a ação produzida na década de 1910 por Washington Luís e Aurélio Becherini no quadro da nostalgia restaurativa, em especial por se realizar (coerentemente) num contexto de poder, em que o autor da encomenda pode ser tomado como coautor intelectual da ação. Note, porém, que, embora restaurativa, a ação não busca reconstituir um passado, mas identificar a mudança como um aspecto da tradição local, legitimador do progresso material dominante. Em outras palavras, o restaurativo é potencialmente ilusivo, sem ser necessariamente óbvio.

Por sua vez, o projeto museológico de Taunay permite um entendimento mais próximo ao conceito, com estrutura e abrangência distintas. Ocorre em circunstância mais complexa, em instituição de memória de grande centralidade, tro, como exemplo dessas operações de construção da tradição na modernidade em contexto recente, mas ainda como possibilidades de visitação renovada ao tema. Em 1977, num 25 de janeiro, a Secretaria Municipal de Cultura, reestruturada dois anos antes, instala a primeira edição do projeto Museu de Rua, idealizado por Julio Abe Wakahara. Herdeira do conjunto fotográfico, que remete aos álbuns organizados pelo Exmo. Sr. Prefeito 60 anos antes, o projeto institucional distribuiu pelas ruas da cidade painéis em grande formato, com pouco mais de dois metros de altura, que apresentavam as imagens de Militão em seus pontos de tomada. Inovadora entre nós por se propor como ação expográfica no espaço da rua, a exposição era em si manifestação clara da coincidência entre o ciclo de estudos sobre o fotógrafo em andamento e a constituição de uma história da fotografia, projeto que se propunha no quadro incipiente do pensar novas soluções museológicas, em especial aquelas voltadas para os acervos audiovisuais em constituição ou reconfiguração naquele momento.

61. Cf. Boym (2001, capítulo 4, Epub). 
62. Cf. Araújo (2006).

63. Boym (2001, capítulo 4, Epub).

64. Cf. Donham (1999). sob um agenciamento de longa duração. Aqui, a noção de documento é tomada pelo valor de face. Por fim, quanto à memorabilia em que se poderiam incluir os postais com aquarelas de Wasth Rodrigues, esta é uma ação assemelhada que ocorre já em deslocamento para o registro laico, constituindose também como modelo plausível para vários procedimentos articulados a partir do quarto centenário de São Paulo.

A interpretação da edição original do álbum de 1887 sob a chave da nostalgia reflexiva, porém, é igualmente plausível. Nesse sentido, a análise das notações textuais deixadas por Militão, que são contemporâneas à publicação e mesmo posteriores, agora em contexto republicano, pode permitir novos desdobramentos. ${ }^{62} \bigcirc$ conceito se aplicaria na proposição em si do projeto, organizado a partir de imagens feitas duas décadas antes; como também na agência do autor ao realizar os novos registros, na produção visual enfim, ao estruturar a narrativa do álbum.

É oportuno rever como Svetlana Boym, no livro citado, comenta a complexidade e potencialidades das tradições inventadas na modernidade:

Invented tradition does not mean a creation ex nihilo or a pure act of social constructivism; rather, it builds on the sense of loss of community and cohesion and offers a comforting collective script for individual longing. There is a perception that as a result of society's industrialization and secularization in the nineteenth century, a certain void of social and spiritual meaning had opened up. What was needed was a secular transformation of fatality into continuity, contingency into meaning [grifo nosso]. ${ }^{63}$

As narrativas que se articulam nas contínuas apropriações das imagens de Militão, através do exacerbamento do procedimento comparativo em especial, constituem peça-chave desse processo de construção da tradição visual local. Ainda que seja necessário distinguir entre pequenas e grandes narrativas, expressas em ocorrências como os álbuns ou no percurso imagético de larga duração, é oportuno retomar o comentário de J.D.Y. Peel $(1995)^{64}$ sobre a narrativa:

[Narrative] is a critical instrument of human agency, for it is the principal means by which agents integrate the temporal flow of their activities. Putting it another way, human beings produce sociocultural form through an arch of memories, actions, and intentions. Narrative is the way in which that arch may be expressed, rehearsed, shared, and communicated. It is this which gives human action its inherent historicity or lived-in-timeness and which requires an anthropology that, to be adequate to its subject matter, should be essentially historical. 
A partir do que Donham afirma:

Not only is narrative key for understanding particular historical actors, but also the way that narratives interact and intertwine over time, are copied, changed, and passed across cultural space, is central to the task of constructing historical ethnographies. ${ }^{65}$

Outro recurso teórico plausível está no conceito de cronotopo desenvolvido por Mikhail Bakhtin (1937-1938, 1998), que categoriza estruturas discursivas enquanto configurações de tempo e espaço. Sua contribuição original no campo da literatura tem sido empregada no estudo de outras formas poéticas, inclusive visuais, nas últimas décadas.

Sua aplicação ao Álbum comparativo original, contudo, não parece adequada, se tomado em seu todo. $\bigcirc$ que ocorre ao longo daquela narrativa, como observado anteriormente, não permite propor nem mesmo um hipotético cronotopo do comparativo com algum rigor.

Os três núcleos propostos na interpretação daquela obra - introdução (1887) rumo à área central, pares comparativos (1 862-1887) dessa região, e conclusão em rumo oposto (1887) - permitem algum avanço, tomados em separado. Estes núcleos revelam apropriadamente um intercâmbio de regimes discursivos entre cronotopos ao longo do percurso, do caminhar. ${ }^{66}$ Em outras palavras, o deslocamento pela cidade, estruturado na narrativa original de Militão, opera conforme uma contiguidade espacial, desenvolve-se no eixo sincrônico, atento aos espaços adjacentes. Entremeado à narrativa geral, o conjunto central do álbum, comparativo, opera ação diacrônica, enfatizando o espaço em transformação no tempo.

Quando muito seria plausível discutir aqui, embora se acredite não haver elementos suficientes para a conceitualização, que Militão atende a uma possível cronotopia dos álbuns de vistas urbanas do século XIX. ${ }^{67}$ Caso oposto, porém, tem lugar nas edições organizadas quase três décadas depois por Washington Luís e Aurélio Becherini, quando parece sustentável propor a constituição de uma cronotopia do comparativo.

Para caracterizá-la mais claramente, seria necessário, contudo, avaliar as quatro edições, em seus oito volumes, procurando evitar um delineamento sumário. Como operaria esse cronotopo? Ele toma um mesmo espaço, ou melhor, um objeto no espaço e articula um afastamento no tempo. Cria assim um passado (em forma visual) imediato, uma profundidade histórica digamos, que se dá no álbum quase simultaneamente ao ser folheado, mas configurado
65. Ibid., p. 180.

66. Oportuno apontar que as recorrentes tomadas das imagens segundo a perspectiva no eixo longitudinal das ruas, bem como a ênfase nas edificações em detrimento do elemento humano, parecem reduzir um paralelo eventual com oflâneur baudelairiano. Tal modelo talvez não seja possível entre nós naquele momento. As ruas são equipamentos precários na São Paulo da década de 1860. O substantivo "equipamento" parece inadequado pois implica em reconhecer como tal algo em si improvisado. É difícil a locomoção a pé e recorrer ao cavalo, ao muar ou à carruagem está restrito a poucos. Além disso, até mesmo a área de circulação no dia-a-dia, implicando aí fatores como status $q u o$, função social e gênero, etc., deve ter permanecido por muito tempo severamente reduzida aos seus habitantes.

67. Em uma especulação inicial, a partir de tipologia genérica do formato álbum de vistas, poderíamos caracterizar a ênfase nas ruas principais, e nos edifícios de uso coletivo, englobando variações conforme contexto como igrejas, pontos de encontro social, edifícios governamentais, etc. 
em seu todo como um conjunto de "eixos paralelos" no tempo, um feixe de aquis, que apaga, ou mais precisamente impossibilita pelo excesso, a percepção sincrônica. No limite, esses futuros paralelos que o modelo implica esgotam-se em si mesmos e despedaçam o presente.

Apenas como observação necessária, o Álbum comparativo (1887) surge, em suma, como obra potente quanto ao tema do tempo. Suas imagens apresentam o referente edificado, o espaço construído, em detrimento do humano. Este é acessório, embora presente como elemento móvel no espaço, embora seja ele mesmo o grande ator da rua. Ainda assim os humanos aqui registrados, meros vultos por vezes, podem ser entendidos mais como documentos, sujeitos a um regime menos representacional do que aquele que se dá nos retratos de estúdio.

Não há, por outro lado, nessas imagens um tempo mensurável, digamos. A precariedade dos registros, a deterioração das imagens e, talvez, como resultado de ação intencional do autor, não é possível distinguir a escala duracional do ano, das estações. Há apenas dia, nem manhãs ou tardes com alguma precisão, mas um dia abstrato, desnaturalizado (embora aqui ou ali as sombras de um sol a pino atraiam o olhar). Nem tempo biológico, nem tempo do trabalho podem ser caracterizados, nem ritmo urbano preciso, apesar de imagens de alguns logradouros com flagrante atividade comercial. Isso não implica que um tempo modorrento se instale ou que uma suspensão de tempo tenha lugar, apenas que aqueles tempos não parecem representados. Não há naquelas imagens um ritmo propriamente. Nem mesmo as igrejas com seus relógios e ritos marcam o tempo. Única exceção clara nesse encadeamento é o registro em 1862 do Pátio do Colégio, sede da administração provincial, que surge tomado por mais de uma centena de pessoas, número surpreendente para uma população urbana de pouco mais de 10 mil habitantes. Resultado oposto pode ser contemplado na obra de Pedro Correa do Lago (2001), ao analisar o conjunto expandido das imagens de Militão para o período 1862-1863, o que ressalta as escolhas feitas pelo fotógrafo ao editar seu álbum ao final da década de 1880.

Por sua vez, será que a dupla chave presente na apropriação da década de 1910 - ausência de ritmo temporal da cidade e criação de eixos paralelos de fluxo temporal - teria instaurado outra temporalidade que, soberana, padrão, neutra, permitiu a permanência das imagens, sua reiteração, por mais de um século? Os dípticos comparativos parecem nesse contexto estabelecer um fluxo rumo ao espectador, ele mesmo tomado como locus do futuro, num original processo de vínculo com o leitor da nova série de álbuns. Tal relação, se ainda enfraquecida para os seus contemporâneos, ganharia intensidade com o tempo. 
É curioso perceber que, nos dois casos, em 1887 ou na década de 1910, não há ocorrência da ruína, nem como conceito, nem como evidência, ao menos nesse momento comparativo. A ênfase parece ser a mudança, entendida apenas em sua afirmação contínua. Em vez da ruína, ${ }^{68}$ estabelece-se mola propulsora rumo a um futuro, abstrato e indefinido. Em outras palavras, dá-se forma visual à temporalidade do progresso. ${ }^{69}$

Antes que se configure na abordagem deste ensaio uma indisposição quanto ao recurso comparativo, seria oportuno lembrar que a comparação é um instrumento elementar para o pensamento tanto verbal como visual. A produção de conhecimento recorre também a procedimentos muito próximos, como a sequência e a serialização, etapas possíveis para geração de tipologias, identificando estruturas, dinâmicas, etc. Esses recursos são recorrentes com algum destaque nas artes visuais contemporâneas, menos preocupadas com o referente e articuladas em torno do conceitual. Aparecem ainda associados a configurações que se expressam por vezes mais no espaço expositivo (convencional ou não), através da articulação das obras em mosaico, nuvens, sites specifics.

No campo da fotografia, é possível exemplificar essas operações no primeiro modernismo, como na obra do alemão August Sander (Alemanha, 18761964) em seu projeto Pessoas do Século XX, que procurava criar um retrato da sociedade alemã centrado na constituição de tipos sociais. Ou, mais adiante, na produção do casal de fotógrafos Bernd e Hilla Becher, que registrou ao longo da década de 1960 a arquitetura industrial da região alemã do vale do Ruhr, prestes a desaparecer, criando séries extensas de diferentes categorias de construções gigantescas marcando a paisagem.

Essas ações de serialização estão próximas do ato comparativo. Têm recortes e agências distintas, caso a caso. Exploram, às vezes, mais a forma pura e sua variação, desconsiderando funções originais dos objetos. Outros procedimentos mantêm alguma ligação mais direta com o comparativo, por exemplo, como os propostos em formatos como o diário pessoal e pelo tema do arquivo, práticas com destaque nos últimos 20 anos.

No primeiro caso, basta apontar o recurso do retrato diário lou registro de ações repetitivas), em imagens similares, associadas ou não a notas textuais, cobrindo longos períodos. No segundo caso, o arquivo, talvez o mais impactante e complexo tema, todas essas operações são acionadas ao refletir sobre a produção de memória, seus agentes e poderes em potencial. E, no limite, quanto ao tema do arquivo, até mesmo os próprios espaços institucionais - museus e eventos como as bienais internacionais - foram tomados em si como objetos dessa reflexão. ${ }^{70}$
68. Sobre a figura da ruína, é necessário apontar que, raramente, nos álbuns em questão datados da década de 1910 , surgem imagens isoladas de antigos casarões, por vezes prestes a serem demolidos, acompanhadas de legendas que indicam expressamente - "fotografada por ordem do senhor" [prefeito] (cf. Álbum Comparativo da Cidade de São Paulo até o ano 1916 (1862-1900-1916) São Paulo: 1916, última imagem). Ainda sobre a ausência da ruína seria relevante apontar, apesar da recorrência em livros por longo período do par de termos - São Paulo antigo/São Paulo moderno -, que a passagem do tempo nesses álbuns não ocorre de forma convencional, pois não há envelhecimento, degradação. A cada momento, o registro fotográfico apresenta os referentes em seu "esplendor", em novas configurações.

69. Como nota paralela, prefiro o termo progresso a futuro. O devir histórico configurado nesse modelo apresenta um horizonte de expectativas delimitado, definido como percurso inexorável, sem desvio, a que não se pode escapar ou sobre ele agir.

70. Um exemplo, a partir da problematização do arquivo, está em parte significativa da obra da artista Rosângela Rennó (Belo Horizonte, 1962), entre elas a mostra e o livro O arquivo universal e outros arquivos (Cosac Naify, 2003). Sobre o primeiro procedimento, o diário, não raro, por exemplo, em produções que ocupam redes sociais como Instagram, pode ser identificado também na produção desta artista como em Espelho diário. Trabalhando com textos e não imagens, a instalação e livro lançado em 2009 (Edusp) reúnem notícias publicadas em jornais brasileiros, coletadas ao longo de 8 anos, em que o prenome da artista 


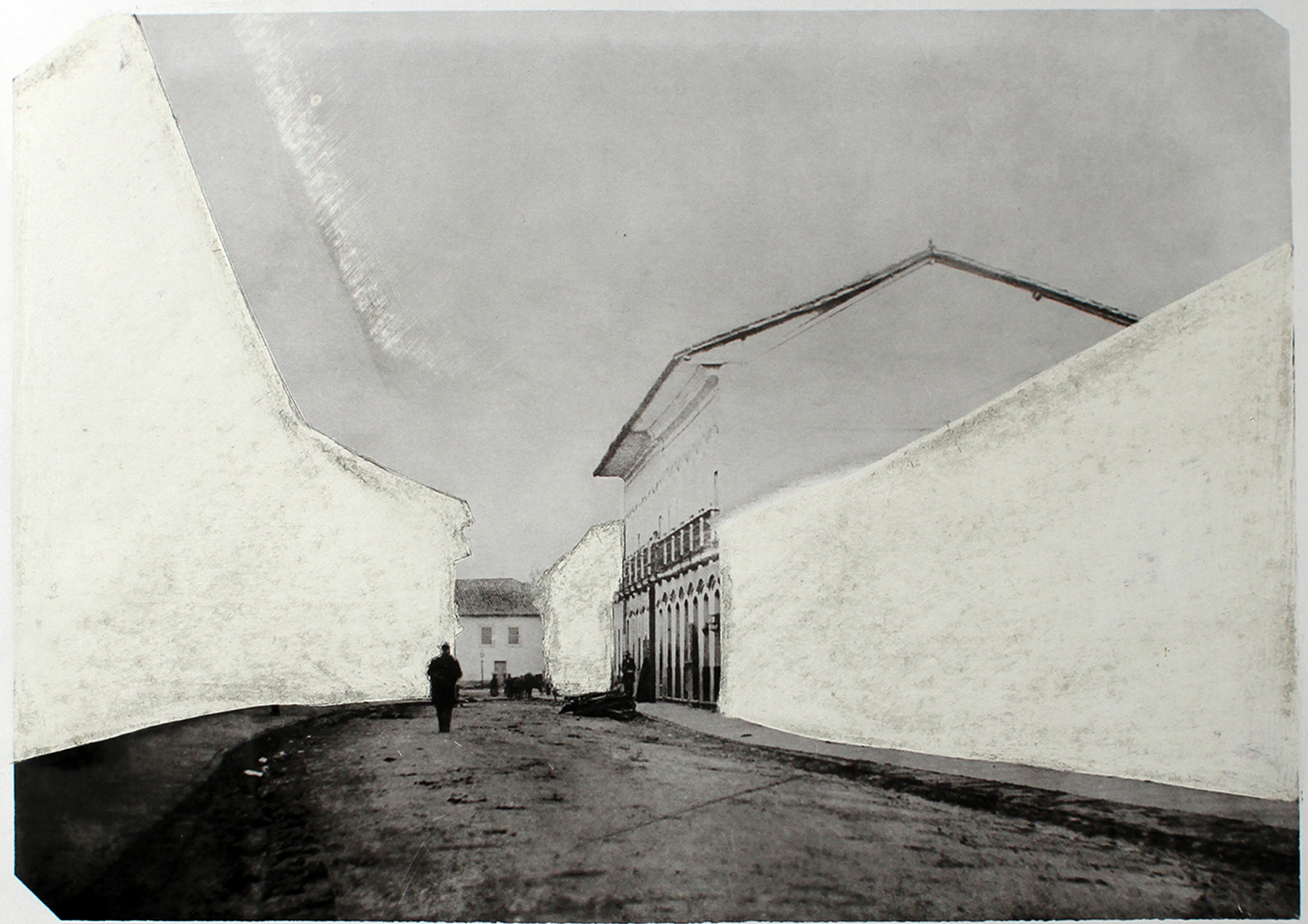

Rua do Carmo, 1862 [negativo de vidro]. Foi local de residências abastadas na primeira metade do século xIX, a exemplo do sobrado da marquesa de Santos, visto à direita, em destaque. À esquerda, a lateral do Recolhimento de Santa Teresa e, ao fundo, parte da Igreja dos Jesuítas.

Figura 6 - Thiago Navas. Série Apagamento/Encobrimento (2015-2016). Intervenção sobre página impressa com imagem de Militão Augusto de Azevedo (Rua do Carmo, 1862), dimensões 27,5 × 26,5 cm. Acervo pessoal do artista. 
Tomemos agora as obras apresentadas na primeira parte do presente ensaio. Sobre os dípticos de Patrícia Cardoso, ocorrência única em sua produção, as obras funcionam em nossa abordagem como gatilho para pensar a relação entre o contemporâneo e uma tradição visual em formação.

Os registros urbanos articulados em dípticos parecem banais. Ao visitante, sem conhecimento das referências históricas, as obras operam diretamente sobre o tema da falta de sentido muitas vezes para as denominações de logradouros. ${ }^{71}$ Um dos pares aproxima a Rua Washington Luís, no centro, com a Avenida Washington Luís, na região do Aeroporto de Congonhas. $\bigcirc$ que une tais vias além do nome? Contexto urbano, sua ocupação, o estado atual, tudo é distinto. No quadro deste ensaio, a referência no título da obra ao gestor municipal e historiador ganha tom irônico. O outro par aproxima a Rua Nove de Julho, em Santo Amaro, com a avenida do mesmo nome na região dos Jardins, que exaltam a data comemorativa de especial valor regional, elemento de centralidade ao longo do século XX para a construção de um imaginário paulista que reforça os valores de autonomia e empreendedorismo. ${ }^{72}$

A quebra operada por Cardoso no modelo comparativo, aproximando espaços/objetos distintos em tempo similar, em vez de um mesmo objeto em tempos distintos, comenta de certa forma a finalidade em si do procedimento como forma de conhecimento e como instrumento de análise. A regra matemática - só é possível comparar grandezas da mesma espécie usualmente generalizada no sentido de que só é possível comparar o que é semelhante é desmontada. Afinal tudo é comparável a partir dos fins e parâmetros conceituais postos em questão.

Os dípticos permitiram a interpretação detonadora do tema proposto neste ensaio. A série retoma a estratégia dos pares comparativos urbanos, mas questionaos ao problematizar os parâmetros de comparação. Não mais um espaço no tempo, mas espaços em abordagem conceitual. Uma ação, em parte irônica ela mesma, que traz condições para olhar a produção contemporânea em busca de ocorrências e questionamentos similares.

Marcelo Zocchio, na série Repaisagem, procede de forma distinta. Tensiona simultaneamente o registro fotográfico como documento e o procedimento comparativo, através de ação em viés que evita o comentário direto, explícito, a tais aspectos. Aproximar a série ao conceito de nostalgia reflexiva, proposto por Boym, é oportuno. As cenas urbanas, em pontos conhecidos da cidade, são facilmente identificáveis. $\bigcirc$ perturbador, como comentamos na primeira parte do ensaio, é a tensão visual que surge repentinamente ao identificar-se que elementos da imagem são em verdade está presente, ocorrência agora tomadas como matéria para operação artística. O título, numa manobra dupla, aponta tanto para a ocorrência dos nomes como para o suporte em questão ao referir-se ao jornal inglês Daily Mirror. Uma abordagem sobre os arquivos, com ênfase nos conflitos entre memória, poder e estatuto documental marca uma geração mais nova de produtores visuais na qual seria possível destacar a produção em meados da década de 2010 do artista Rafael RG (Guarulhos, 1986).

71. Segue nessa linha a interpretação do crítico Cauê Alves, autor do texto da mostra Outra margem, mencionada anteriormente, conforme documento textual cedido pela artista: "A artista fotografa ruas e avenidas que possuem o mesmo nome, como Av. Washington Luiz / Rua Washington Luíz e Av. Nove de Julho/ Rua Nove de Julho. Colocando lado a lado fragmentos de locais diferentes da cidade, ela exalta [a] falta de relação e identidade entre nome e lugar. Ao aproximar paisagens diferentes e mostrar a arbitrariedade dos nomes, a artista se distancia do registro objetivo em direção a uma espécie de colagem, uma justaposição de horizontes de uma cidade sem identificação. O modo como monta as fotos e escolhe os ângulos, em trabalhos anteriores, reorganiza o caos urbano."

72. A denominação do logradouro faz referência à Revolução Constitucionalista de 1932, ocorrida entre julho e outubro daquele ano, em que tropas paulistas confrontam o governo federal. O evento insere-se no contexto do golpe de estado de 1930, que derrubou o então presidente da República, Washington Luís. 
73. A imagem da epifania "como raio" é inspirada em Walter Benjamin, a partir de suas Teses sobre o conceito de história (1940). Ali surge em momentos diversos, aplicada por vezes em circunstâncias distintas. Cf. Benjamin (1994).

74. O domínio técnico do processo é fator relevante, mas no limite o tratamento digital de imagem não tem peso decisivo. Seria possível a produção no processo analógico, mas certamente em série menos extensa e com obras em formato menor.

75. Zocchio, na verdade, acaba incorporando ao repertório de trabalho novos autores, que foram identificados pela historiografia apenas na virada para o século 21 como o fotógrafo comercial Vincenzo Pastore (Itália, 1865São Paulo,1918), referenciado aqui pela paisagem humana em seus registros, no contexto menos hierarquizado das ruas.

76. O conceito é apresentado em conferência realizada em 1967, mas publicada apenas duas décadas depois. Cf. Foucault (1984). registros de outra temporalidade num esmagamento de camadas no tempo. $\bigcirc$ espectador, independentemente de seu conhecimento sobre a produção imagética utilizada ou sobre a história local, acaba por decodificar gestos, roupas e outros índices dessa "temporalidade invasiva", apontada por Guilherme Wisnik, como citado anteriormente. Não se trata do remanescente geológico, da evidência arqueológica, da estratégia do palimpsesto, mas algo que se revela como epifania, condensado como raio. ${ }^{73}$

A série, de longa duração, articulada por toda uma década, não apresenta subséries ou derivações claras. Ganha mais consistência nesse intervalo pelo crescente rigor técnico e sensibilidade no processo de tratamento e articulação de imagens. ${ }^{74}$ Esse aspecto, aliado a uma atenção clara sobre a presença humana nos registros, acaba em algumas obras por trabalhar com destaque sobre o humano em detrimento do fato físico, algo tão distinto das imagens de Militão ou Becherini. ${ }^{75}$ Assim, em registros com grande número de pessoas, o efeito surge revigorado. Vultos de diferentes temporalidades se confrontam, mantendo a surpresa do espectador ao distinguir subitamente esses traços, suas diferenças e permanências.

O termo repaisagem, que dá título à série, pode ser interpretado em suas literalidades possíveis como rever as paisagens enquanto espaço associado a um olhar, como também por derivação - retomar, retornar, refazer uma paisagem. Em suma, um modo de revitalizar a fotografia de paisagem em sua dupla ontologia: registro documental e representação.

A potência da obra permite aproximações reiteradas. Certamente um modelo cronotópico potente pode ser delineado, um modelo que comenta o simultâneo da imagem comparativa, que realiza esses tempos num mesmo espaço: espaço que parece dobrar-se. Dobras do tempo ou do espaço? Não, dobras de suas representações, nem por isso fało menos problemático. Ainda que a operação entre temporalidades se revele em segundo momento, ainda que esses tempos se apresentem em simultaneidade e não em sucessão, a série submete o espaço enquanto temporalidade a seu modo, como o fazem as imagens comparativas em Militão e seus sucedâneos. E assim, estabelece-se um pensamento visual crítico sobre esse longo percurso histórico antes comentado.

Outra possibilidade de interpretação da mesma série é possível a partir do conceito de heterotopia proposto por Michel Foucault (1926-1984). ${ }^{76} \mathrm{O}$ termo designa espaços que articulam camadas de diferentes significações ao estabelecer relações com outros espaços, alteridades físicas e mentais. 


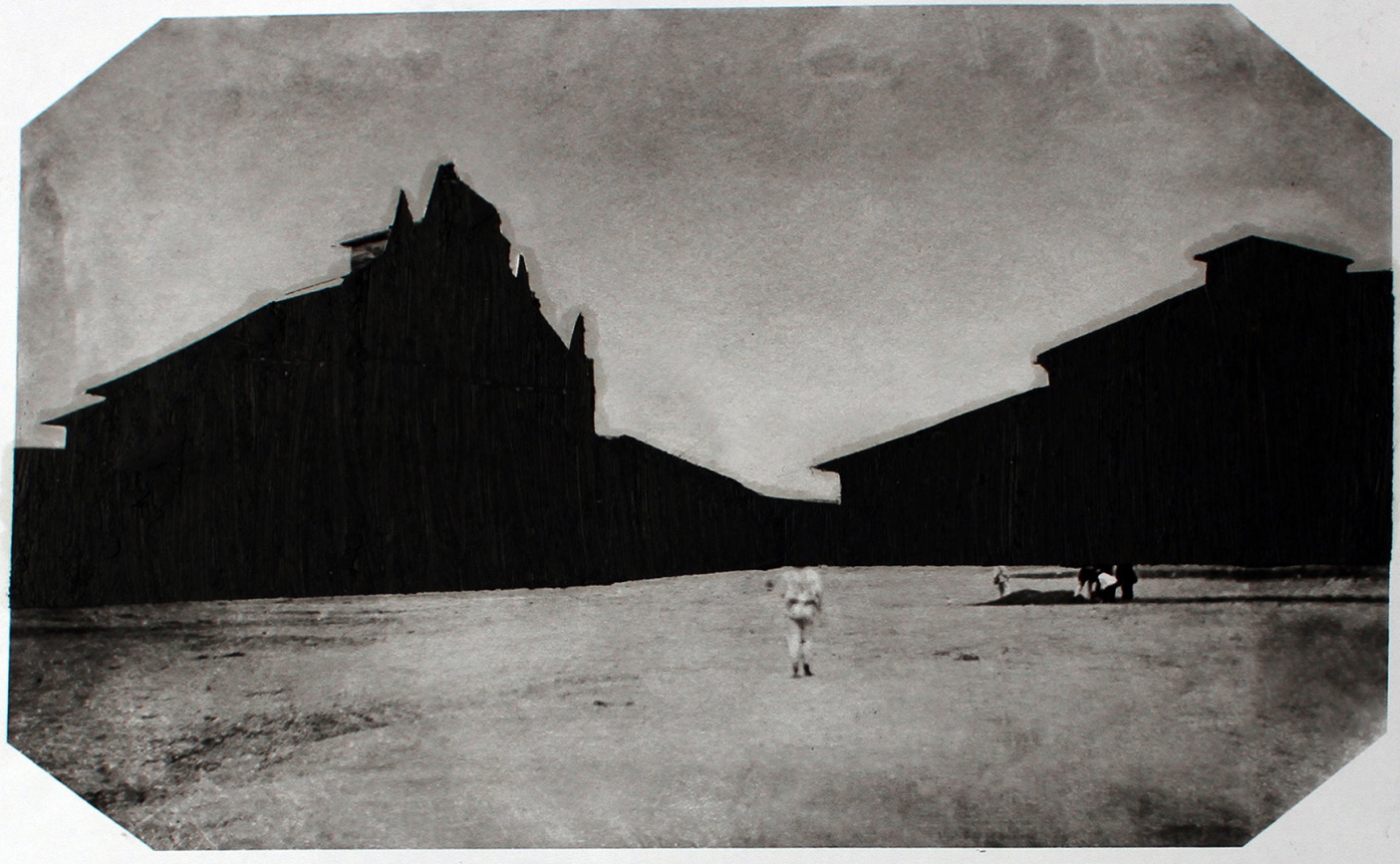

Largo da Cadeia, 1862 [negativo de vidro]. Oposta à cadeia e ao Paço Municipal estava a Igreja N. S. dos Remédios. Ao centro, na separação entre os prédios, a estreita passagem para o largo do Pelourinho, a rua da Glória e o caminho para Santos.

Figura 7 - Thiago Navas. Série Apagamento/Encobrimento (2015-2016). Intervenção sobre página impressa com imagem de Militão Augusto de Azevedo (Largo da Cadeia, 1862), dimensões $27,5 \times 26,5 \mathrm{~cm}$. Acervo pessoal do artista. 
77. Nesse sentido, seria oportuno comentar que, no panorama brasileiro, projetos artísticos semelhantes são raros. Em único registro conhecido, Marcello Cavalcanti realizou em 2017, na cidade do Rio de Janeiro, a mostra Augusto Malta revival. As circunstâncias gerais são próximas: conjunto iconográfico referencial produzido por Augusto Malta (Paulo Afonso/AL, 1864-Rio de Janeiro, 1935), tratamento digital de imagem e fusão de registros urbanos. O resultado está bem distante da série de Zocchio e não necessariamente por questões de perícia. A escolha das inserções, os recortes, as camadas... tudo se realiza de modo distinto. A inexistência no quadro carioca de referência de fotografia comparativa da forma que se deu na obra de Militão e no seu percurso no tempo, constructo simbólico, acaba sendo um vetor ausente, que reduz ainda mais o resultado do projeto. Ver imagens do ensaio em https://www.facebook.com/augustomaltarevival. Acesso em: 9 jul. 2018.
A interpretação é possível, ampla, a partir da vertente da ilusão operada, na qual um espaço íntegro surge de fragmentos de distintas temporalidades em simultaneidade. A tensão entre essas temporalidades parece central para o conceito heterotópico, tensão vista como vetor-chave da obra de Zocchio. ${ }^{77}$ A aplicação do conceito nos últimos anos, em especial na geografia humana, identificando determinados lugares como entidades heterotópicas por articular referências culturais de recortes distintos, parece ser a aproximação que justifique pensar a série Repaisagem mediante tal conceito.

O conceito heterotopia parece de mais fácil aplicação, em exemplo distinto, com efeito menos contundente, na obra do fotógrafo Arnaldo Pappalardo (São Paulo, 1954), na mostra Tavoletta, realizada no Museu da Casa Brasileira (SP, 2013). Nela, o fotógrafo apresenta série homônima, com fotos de paisagem da área central da cidade, em que imenso espelho, em posições distintas, reflete e funde o panorama em redor numa única imagem. Dessa forma, cada imagem integra, funde e expande pontos de vistas que no registro realista se excluiriam, em uma operação que, a seu modo, movimentos da vanguarda europeia das décadas de 1920 realizaram sob outros agenciamentos.

Para finalizar, retomando a conceituação proposta por Svetlana Boym, fica em questão se a nostalgia e seus modos restaurativo e reflexivo têm lugar de forma excludente apenas. Seria possível propor que sejam constituídos, em alguns casos, como possibilidades entrelaçadas? Zocchio, por exemplo, ao publicar o livro Repaisagem São Paulo (2012), um extenso ensaio de imagens da série, inclui um adendo final em que as fotos originais estão listadas, com reproduções e identificações. Esse procedimento é índice restaurador? Ou sinal do contexto histórico, do estatuto da pesquisa de imagem praticada, eco de uma historicidade acadêmica difusa?

Thiago Navas, na série Apagamentos/Encobrimentos, permite completar a presente trajetória que parte em Cardoso de um gesto que aponta para uma revisão da imagem comparativa, em Zocchio pela problematização do registro documental e da operação sobre espaço-tempo, e agora em sua obra apresenta uma interação sobre memória, autoria, autoridade e tradição visual. A seu modo, todas essas questões operam no conjunto das obras analisadas com inflexões e abrangências distintas.

Nesta última série, o tema da fotografia comparativa, seja no catálogo seja na mostra realizada em São Paulo, não entra em questão. Não de forma direta, embora o evento tenha se dado em ponto quase central, na sede da Caixa Cultural, em frente ao remanescente (encoberto ele mesmo) do Largo da Sé, fronteiriço ao Pátio do Colégio, core do território ocupado pela cidade na década de 1860. 
Como apresentado na primeira parte, o artista toma como suporte direto para sua obra o livro Militão Augusto de Azevedo (2012), publicação de editora de prestígio local em parceria com secretaria municipal, que, através de diversas subunidades, é guardiã do conjunto produzido por Militão como também da iconografia derivada realizada na década de 1910. Portanto, edição passível de ser tomada como interpretação oficial, recorte institucional.

Através de dois modos de operação - eliminação e encobrimento, é possível propor que, ao intervir diretamente nas imagens impressas, Navas fere o livro de arte como suporte de autoridade e, no limite, a autoria das próprias imagens. E, simultaneamente, aponta para a condição da reprodutibilidade imagética que tem no livro um suporte de destaque. Sua intervenção direta sobre a imagem impressa tanto descaracteriza, desloca a autoridade do livro, do produto institucional historiográfico, como ignora-o para avançar. Estabelece uma nova imagem, como coautor, como visualidade posta em movimento. Entenda-se nesse quadro as operações do artista sobre autoria e autoridade. ${ }^{78}$

Nos dois grupos de imagem articulados na série, elementos dos registros são suprimidos. Em Apagamentos, todo o conjunto edificado é eliminado, salvo os raros locais remanescentes ainda hoje. ${ }^{79}$ Trechos das páginas impressas são habilmente lixados, formando uma massa branca, que surge na vertical como ondas ao redor dos vultos indefinidos dos passantes, paredões de ondas que formam ruas.

A percepção sobre a eliminação do que não perdurou, das construções enfim, não é evidente à primeira vista, apenas é descoberta como estratégia em segundo momento. Aqui resta o espaço pleno das ruas sob uma luz, um céu, que até então não parecia evidente (por todo um século). Curioso twist ao redor do teor documental, pois, eliminado o que parecia mais em evidência - as edificações -, outras camadas parecem surgir, como a rua, espaço de vivência em que a experiência moderna das cidades terá lugar. ${ }^{80}$ A cidade surge com força, mas agora como manifestação física nova cuja imanência se torna visível de forma inesperada. ${ }^{81}$

Encobrimentos, o grupo de imagens em paralelo, contrapõe ironicamente obras que se poderiam associar a negativos, numa alusão ao processo técnico fotográfico em que foram gerados os registros. Agora Navas realiza ação oposta, e o que não permaneceu é eliminado, não pela agressão física ao suporte da imagem, mas através do encobrimento por camada homogênea de tinta preta. $\bigcirc$ curador Paulo Gallina, oportunamente, comenta no catálogo a aproximação dessa operação de silenciamento a uma prática da própria modernidade nas décadas iniciais do século XX ao impor novos arranjos à tradição cultural. ${ }^{82}$
78. A programação paralela da mostra Apagamentos deixa mais evidente as interfaces relativas a memória pessoal e memórias coletivas em seus diversos níveis e interações. Navas promoveu visitas em grupos a diversos pontos do centro e estimulou a produção e edição de imagens além do registro da fotografia de rua convencional. Embora seja possível questionar se essas ações não estão aquém da proposta do ensaio apresentado, elas evidenciam a amplitude da proposta expográfica.

79. Os dois subgrupos mencionados surgem na exposição de forma menos evidente, editados em mosaicos próximos num mesmo am biente, ao contrário do catálogo que os isola. Nem os marcos cronológicos das imagens originais parecem ser relevantes no conjunto exposto, apesar de que um paralelismo ocorra aqui ao contrastar duas modalidades de apagamento das imagens

80. Entende-se assim o comentário de Fraya Frehse, em palestra referenciada anteriormente, que especula se o que há de moderno, de modo mais relevante, na obra de Militão não seria o fato de ter fotografado o espaço das ruas em si mesmo. Indo além, o argumento é plausível em especial se considerarmos os registros realizados em 1862, momento de sua formação como fotógrafo num contexto em que a prática das vistas fotográficas urbanas não tem ocorrência similar, em tal extensão, em São Paulo.

81. Essa ruptura, digamos, parece implodir o monumento, procurando estimular o espectador rumo a uma crítica representacional, proativa, de volta às ruas.

82. O texto curatorial é breve nesse aspecto, mas com precisão aponta ainda para aspectos relevantes como a 
aproximação do conjunto Encobrimentos ao monumento realizado em Berlim, pelo arquiteto norte-americano Peter Eisenman - Holocaust-Manhmal, inaugurado em 2005. Cerca de 2.700 blocos de concreto com altura variável de quase cinco metros, espalham-se por grande área em reticula ortogonal, mas submetidos espacialmente a certa irregularidade em sua distribuição, o que estabelece um ambiente confuso, tenso. $\mathrm{O}$ aspecto fantasmático na obra de Navas talvez venha daí, de intervenção com resultado assemelhado através do perfil marcado das construções contra o céu.

83. Jorge Luis Borges (18991986): conto Pierre Menard, autor del Quijote, datado de 1939 , e o miniconto Del rigor en la ciencia, datado de 1946.

84. O elo conceitual com o termo genius loci é claro, sendo aproximação com certa recorrência no panorama local de artes visuais ou arquitetura. Como exemplo, a mostra coletiva Genius loci - o espírito do lugar, realizada em 2002 no bairro de Vila Buarque por 30 instituições locais, reunindo obras de jovens artistas contemporâneos a fotógrafos da década de 1960 .

85. Navas continua em sua produção posterior a articular diversos vetores agenciados na série Apagamentos / Encobrimentos agora no grupo de obras intitulado Desvios, composto pelas séries Aparições, Lábaros $e$ Deslocamentos, produzidas a partir de 2018. Nelas, com resultados distintos, o artista opera com índices da ação humana edificada eliminada da paisagem, marcos urbanos institucionais, que se revelam por exemplo através de marcas in loco, sobre ruas e calçadas, ao delinear o perímetro de antigas construções como o Convento dos
Difícil não associar à série, construída através dessa dupla chave, com a idealização de imagens de uma cidade realizada sob a inspiração borgiana da cartografia em Sobre o rigor na ciência, mas agora eliminando sua representação para redescobri-la. Ou ainda, do mesmo autor argentino, tomando da criação reversa em Pierre Menard, autor do Quixote, ${ }^{83}$ ocultando cada parte para melhor observá-la.

Na mostra realizada pelo artista em 2016, no hall do edifício da Caixa Cultural São Paulo, à frente da exposição, a obra Ruído, único objeto tridimensional em grande escala no conjunto, pode passar despercebida, mas sua inserção é precisa: um sinal à entrada. Ali, em círculo, seis moldes em gesso branco mostram, em negativo, pela ausência do volume do objeto a que remetem, parte de uma das colunas do próprio edifício, presentes no andar térreo. Moldes vazios, de seção semicircular, voltados para fora, trazem em si o mesmo modelo processual ao redor do qual a série de imagens se articula ${ }^{84}$ Os moldes reversos são claros: não ocultam, revelam mais intensamente. $\bigcirc$ convexo se torna côncavo. $\bigcirc$ que as colunas concentram Ruído coloca em expansão.

Memória, autoria, autoridade e tradição visual são conceitos mobilizados por Navas de modo peculiar. Ao fazer suas as imagens impressas, reconfigurandoas como fruto da dimensão pessoal da memória, da experiência da cidade, ele expõe o processo reflexivo frente às histórias da visualidade, através do conflito entre indivíduo, comunidades e Estado.

Afastando-se diretamente do aspecto comparativo, a série Apagamentos/ Encobrimentos a um só tempo destrói e expõe o que pode haver de documento nas imagens reiteradas de Militão. Curiosamente não há ruína possível aqui, mas um mecanismo de desvio do olhar para o espaço das ruas, para a luz, elementos que surgem como construção recente, nova. Resultado algo irônico, porque nunca se falou das imagens de Militão através de elemento tão constitutivo da fotografia como a luz, seu registro. $O$ resultado é eficiente porque a destruição em viés que impõe sobre a obra parece possibilitar ver de novo, pela primeira vez, mais uma vez, as mesmas imagens. ${ }^{85}$

Os conjuntos de obras contemporâneas apresentadas sob o título clichê deste ensaio - arte contemporânea em diálogo com a tradição visual - permitem a seu modo pensar um percurso imagético de longa duração - 150 anos. A seu modo, a pesquisa artística - forma de produção de conhecimento pouco aceita no campo historiográfico - parece ter possibilitado nesses exemplos uma reflexão historiográfica potente. $\bigcirc$ estudo da cadeia de imagens e suas derivações no tempo, articulando e apontando temas como tradição visual, memória coletiva e reflexão sobre regimes de historicidades a que estavam sujeitas são possibilidades 
a serem desenvolvidas, mas já revelam como outras gerações podem estabelecer análises renovadoras sobre um patrimônio em criação contínua. Uma estratégia possível se abre, que parece ecoar a frase de Benjamin, em sua tese da história de número 6: "Em cada época, é preciso arrancar a tradição ao conformismo..." 86

As relações de espaço e tempo que operam desde o início na obra de Militão, bem como nos sucedâneos na década de 1910 por meio de Washington Luís e Afonso de Taunay, delineiam exemplos de constructos dentro do próprio campo da historiografia (oficial e acadêmica). Uma antropologia d(ess)a história, em especial da história da cultura visual, da fotografia como é o caso, se impõe com urgência, frente ao complexo leque de agentes envolvidos e às consequências de longa duração que aqui têm lugar.
Jesuítas, no Pátio do Colégio. Ver site do artista: <http:// www.thiagonavas.com $>$. Acesso em: 14 mar. 2019.

86. Cf. Benjamin (1994, p. 224). 


\title{
REFERÊNCIAS
}

\author{
FONTES ICONOGRÁFICAS
}

CARDOSO, Patrícia. Rua 9 de Julbo - Santo Amaro, SP/Avenida 9 de Julbo-Jardins, SP (2003), díptico. 1. Fotografia colorida, a partir de cromo, 50 x $140 \mathrm{~cm}$. Acervo pessoal da artista.

CARDOSO, Patrícia. Rua Washington Luís - Centro, SP / Avenida Washington Luís - Aeroporto, $S P$ (2003), díptico. 1. Fotografia colorida, a partir de cromo, $50 \times 140 \mathrm{~cm}$. Acervo pessoal da artista.

NAVAS, Thiago. Apagamento/Encobrimento (2015-2016). 1. Intervenção sobre página impressa com imagem de Militão Augusto de Azevedo (Rua do Carmo, 1862), 27,5 x 26,5 cm. Acervo pessoal do artista.

NAVAS, Thiago. Apagamento/Encobrimento (2015-2016). 1. Intervenção sobre página impressa com imagem de Militão Augusto de Azevedo (Largo da Cadeia, 1862), 27,5 x 26,5 cm. Acervo pessoal do artista.

ZOCCHIO, Marcelo. Repaisagem (2005-2015 c.) (Largo Coração de Jesus). 1. Fotografia preto e branco manipulada a partir de imagens do artista e de Guilherme Gaensly. Acervo pessoal do artista.

ZOCCHIO, Marcelo. Repaisagem (2005-2015 c.) (Av. Dr. Arnaldo). 1. Fotografia preto e branco manipulada a partir de imagens do artista e de Guilherme Gaensly. Acervo pessoal do artista.

ZOCCHIO, Marcelo. Repaisagem (2005-2015 c.) (Parque Dom Pedro II) 1. Fotografia preto e branco manipulada a partir de imagens do artista e de Vincenzo Pastore. Acervo pessoal do artista.

FONTES IMPRESSAS

LEMBRANÇAS da vida acadêmica. Correio Paulistano, São Paulo, 20 out. 1864. p. 4.

VISTAS da Academia de S. Paulo. Correio Paulistano, São Paulo, 27 out. 1860. p. 3.

VISTAS photographicas. Correio Paulistano, São Paulo, 9 nov. 1859. p. 3. 
ARAÚJO, Iris Morais. Versões do 'progresso': a modernização como tema e problema do fotógrafo Militão Augusto de Azevedo (1862-1902). 2006. 293f. Dissertação (Mestrado em Antropologia Social) - FFLCH-USP, 2006. (publicada em 2010, Alameda Editorial).

ARAÚJO, Íris Morais. Versões do 'progresso': a modernização como tema e problema do fotógrafo Militão Augusto de Azevedo. Anais do Museu Paulista, Nova Série, v. 18, n. 2, p.147201, jul./dez. 2010.

ARRUDA, Rogério Pereira de. Cidades-capitais imaginadas pela fotografia. La Plata (Argentina), Belo Horizonte (Brasil), 1880-1897. 2011. Tese (Doutorado) - Programa de PósGraduação em História, Universidade Federal de Minas Gerais. Belo Horizonte, 2011.

AZEVEDO, Militão Augusto de. Álbum comparativo da cidade de São Paulo: 1862-1887. Textos: Benedito Lima de Toledo, Boris Kossoy e Carlos A. C. Lemos. São Paulo: Prefeitura de São Paulo, 1981.

BAKHTIN, Mikhail. Formas de tempo e de cronotopo no romance. In: BAKHTIN, Mikhail. Questões de literatura e estética: a teoria do romance. São Paulo: Unesp, 1998.

BALDIN, Adriane Acosta. São Paulo em 1860 pelas lentes de Militão Augusto de Azevedo: a história urbana contada através das imagens. 2006. Dissertação (Mestrado em Urbanismo) PUC-Campinas, Campinas, 2006.

BENJAMIN, Walter. Sobre o conceito da história. In: BENJAMIN, Walter. Magia e técnica, arte e política: ensaios sobre literatura e história da cultura. $7^{\text {a }}$ edição. São Paulo: Brasiliense, 1994, p. 222-232.

BOYM, Svetlana. The future of nostalgia. Nova York: Basic Books, 2001.

CAMPOS, Eudes. A cidade de São Paulo e a era dos 'melhoramentos materiaes': obras públicas e arquitetura vista por meio de fotografias de autoria de Militão Augusto de Azevedo, datadas do período 1862-1863. Anais do Museu Paulista, São Paulo, v. 15, n. 1, p. 11-114, jan./jun. 2007. Disponível em: <https://bit.ly/34ELvb5>. Acesso em: 1 jun. 2018.

CARVAlHO, Vânia Carneiro de. Do indivíduo ao tipo: as imagens da (des)igualdade nos álbuns fotográficos da cidade de São Paulo na década de 1950. 1995. Dissertação (Mestrado) em História Social - FFLCH-USP, 1995. 
CARVALHO, Vânia Carneiro de; LIMA, Solange Ferraz de. São Paulo antigo, uma encomenda da modernidade: as fotografias de Militão nas pinturas do Museu Paulista. Anais do Museu Paulista, Nova série, n. 1, p. 147-178, 1993.

CAVENAGHI, Airton José. Imagens que falam: olhares fotográficos sobre São Paulo (Militão Augusto de Azevedo e 'São Paulo Light and Power Co.', fins do século XIX e início do século XX. 2000. 367f. Dissertação (Mestrado em História Social) - FFLCH-USP, São Paulo, 2000.

DONHAM, Donald. Marxist modern: an ethnographic history of the ethiopian Revolution. Los Angeles: University of California; Oxford: James Currey, 1999.

FERNANDES JUNIOR, Rubens (org.). Aurélio Becherini. São Paulo: Cosac Naify, 2009.

FERNANDES JUNIOR, Rubens; BARBUY, Heloisa; FREHSE, Fraya. Militão Augusto de Azevedo. São Paulo: Cosac Naify, 2012.

FOUCAULT, Michel. Des espaces autres. Conférence au Cercle d'études architecturales, 14 mars 1967. Architecture, Mouvement, Continuité. nº 5, p. 46-49, 1984.

GALliNA, Paulo (coord.). Apagamentos: Thiago Navas. São Paulo: Caixa Cultural São Paulo/ Rocha Comunicação Integrada, 2016. Catálogo de evento. (16 de julho a 25 de setembro de 2016).

GOULART, Paulo César Alves; MENDES, Ricardo. Noticiário geral da Photographia Paulistana: 1839-1900. São Paulo: Imprensa Oficial: SMC: CCSP, 2007

GRANGEIRO, Candido Domingues. As artes de um negócio: a febre photographica. 1993. $266 \mathrm{f}$. Dissertação (Mestrado em História) - IFCH-Unicamp. Campinas, 1994. (publicada em 2000, Mercado das Letras/Fapesp).

KOSSOY, Boris. Militão Augusto de Azevedo e a documentação fotográfica de São Paulo (18621887): recuperação da cena paulistana através da fotografia. 1978. Dissertação (Mestrado) FESPSP. São Paulo, 1978.

LAGO, Pedro Correa do. Militão Augusto de Azevedo. São Paulo: Capivara: Contracapa: IRB Brasil Seguros, 2001.

LE GOFF, Jacques. Documento/monumento. In: LE GOFF, Jacques. História e memória. Campinas: Unicamp, 1990. 
LEITE, Marcelo Eduardo. Militão Augusto de Azevedo: um olhar sobre a heterogeneidade humana e social de São Paulo (1865-1885). 2002. 192f. Dissertação (Mestrado em Sociologia)

- FCL-Unesp, Araraquara, 2002.

LIMA, Solange Ferraz de; CARVALHO, Vânia Carneiro de. Fotografia e cidade: da razão urbana à lógica do consumo: álbuns de São Paulo (1887-1954). Campinas: Mercado de Letras, 1997. $1^{\text {a }}$ reimpressão: 2008.

MENDES, Ricardo (org.). Antologia Brasil: 1839-1900. São Paulo: edição do autor, 2013.

MENDES, Ricardo. São Paulo e suas imagens. Cadernos de fotografia brasileira, São Paulo, Instituto Moreira Salles, n. 2, p. 381-487, 2004.

MENESES, Ulpiano T. Bezerra de. Fontes visuais, cultura visual, História visual. Balanço provisório, propostas cautelares. Revista Brasileira de História, São Paulo, ANPUH, v. 23, n. 45, p. 11-36, 2003.

SÃO PAUlO (Estado). Divisão de Arquivo do Estado. São Paulo em três tempos: álbum comparativo da cidade de São Paulo (1862-1887-1914). São Paulo: Casa Civil: IMESP: Secretaria da Cultura: Arquivo do Estado, 1982.

TASSINARI, Mariana. Sobretempo. São Paulo: Olhavê, 2017.

ZOCCHIO. Marcelo. Repaisagem São Paulo. São Paulo: Dash: Porto de Cultura: Nielsen,2012.

SITES

FotoPlus: Bases de dados bibliográfica e de eventos.

Disponível em: <http://www.fotoplus.com>. Acesso em: 9 jul. 2018.

Marcelo Zocchio

Disponível em: <http://www.marcelozocchio.com.br>. Acesso em: 9 jul. 2018.

\section{Thiago Navas}

Disponível em: <http://www.thiagonavas.com>. Acesso em: 9 jul. 2018 e 14 mar. 2019. 


\section{ENTREVISTAS}

Marcelo Salvia Zocchio. Depoimento ao autor em 22 de novembro de 2016, com registro digital de áudio.

Patrícia de Castro Cardoso. Depoimento ao autor em 7 de agosto de 2018, com registro digital de áudio.

Thiago Briguet Navas. Depoimento ao autor em 17 de outubro de 2016, com registro digital de áudio.

Artigo apresentado em 27/03/2019. Aprovado em 24/09/2019.

\section{(cc) BY}

All the contents of this journal, except where otherwise noted, is licensed under a Creative Commons Aftribution License 